Portland State University

PDXScholar

12-8-1993

\title{
Ethnic Identity Changes Among Hong Kong Chinese Americans
}

Pui-Lam Lo

Portland State University

Follow this and additional works at: https://pdxscholar.library.pdx.edu/open_access_etds

Part of the Anthropology Commons

Let us know how access to this document benefits you.

\section{Recommended Citation}

Lo, Pui-Lam, "Ethnic Identity Changes Among Hong Kong Chinese Americans" (1993). Dissertations and Theses. Paper 4599.

https://doi.org/10.15760/etd.6483

This Thesis is brought to you for free and open access. It has been accepted for inclusion in Dissertations and Theses by an authorized administrator of PDXScholar. Please contact us if we can make this document more accessible: pdxscholar@pdx.edu. 


\section{THESIS APPROVAL}

The abstract and thesis of Pui-Lam Lo for the Master of Arts in Anthropology were presented December 8, 1993, and accepted by the thesis committee and the department.

COMMITTEE APPROVALS:
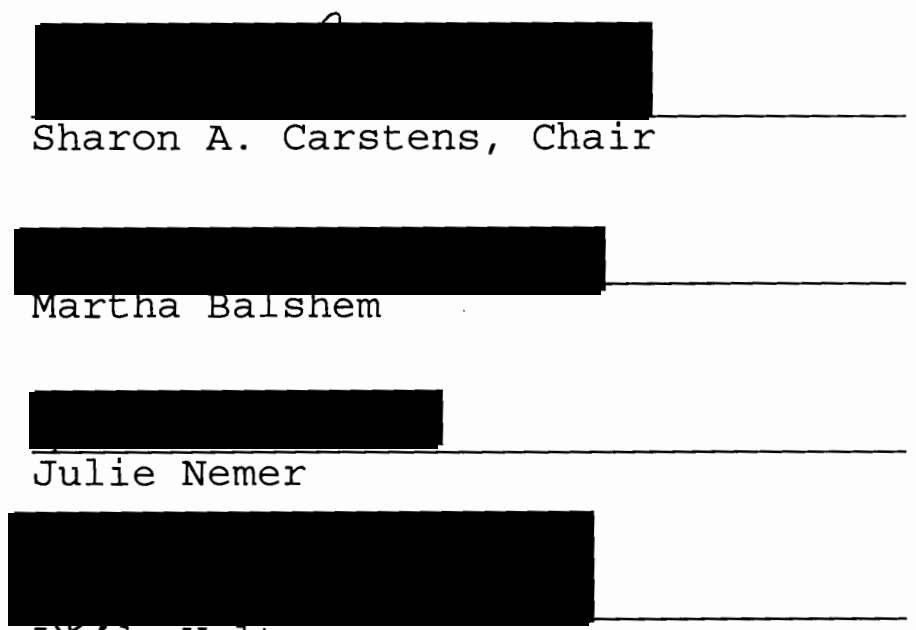

LInda Walton

Representative of the office of Gqaduate studies

DEPARTMENT APPROVAL:

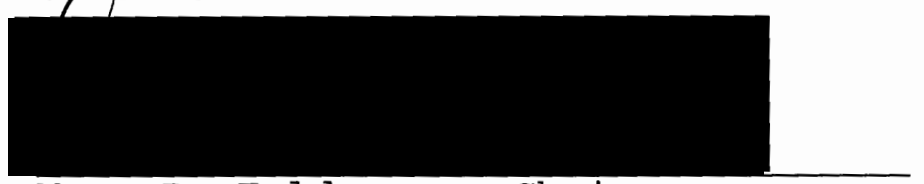

Marc R. Feldesman, Chair

Department of Anthropology

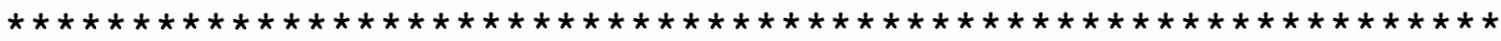

ACCEPTED FOR PORTLAND STATE UNIVERSITY BY THE LIBRARY by

on

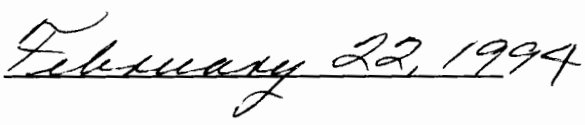




\section{ABSTRACT}

An abstract of the thesis of Pui-Lam Lo for the Master of Arts in Anthropology presented Dec 8, 1993.

\section{Title: Ethnic Identity Changes Among Hong Kong Chinese Americans.}

During the last ten years, the number of Hong Kong Chinese migrating to the U.S. has increased. These new immigrants, with knowledge and life experiences shaped by the urban metropolis of Hong Kong, have begun to influence different aspects of Chinese communities in U.S. cities. A study of this group of Hong Kong Chinese provides a better understanding of how they have adapted to their new environment and how they have come to recognize themselves as Hong Kong Chinese Americans. In reviewing the available literature, very few studies have dealt with the identity changes of this group of people. Hence, the focus of this research was to discuss, specifically, 1) the components that constituted Hong Kong Chinese American identity and how they have changed; and 2) to illustrate the application of practice theory and the concept of habitus to the explanation of the formation of a sense of commonality among Hong Kong Chinese Americans. Twenty-eight Hong Kong Chinese 
who came to the U.S. in the last twenty-five years were selected and agreed to participate in a formal interview. According to the data collected from the informants and observations made on different occasions where Chinese were present, it became obvious that Hong Kong Cantonese language is the most unique component constituting a Hong Kong Chinese identity. Although nine other cultural traits discussed were not unique markers of this identity, these traits reflected changes among Hong Kong Chinese immigrants. Some of the traits endured the drastic changes of the socioeconomic and political situation in the U.S. and surfaced as major traits for them, while some other components lost their significance after the Hong Kong Chinese moved to the U.S. Practice theory and the concept of habitus helps to illustrate the identity labeled by the Hong Kong Chinese immigrants as "Hong Kong Chinese" as rooted in a sense of commonality among themselves. Such a sense is developed from the shared experience they had in Hong Kong and in the U.S. 


\title{
ETHNIC IDENTITY CHANGES AMONG \\ HONG KONG CHINESE AMERICANS
}

$$
\text { by }
$$

PUI-IAM LO

A thesis submitted in partial fulfillment of the requirements for the degree of

\author{
MASTER OF ARTS \\ in \\ ANTHROPOLOGY
}

Portland State University

1993 
DEDICATED TO

CHI-FAI WONG

WHO INTRODUCED ME TO THE

WORLD OF ANTHROPOLOGY 
ACKNOWLEDGEMENT

My heartfelt appreciation goes to Dr. Sharon Carstens, my advisor, whose academic guidance, encouragement and forbearance made the completion of my thesis possible.

I would also like to extend my thanks to Dr. Martha Balshem for her advice and guidance during my graduate studies and her insight into my thesis. My sincere appreciation to Dr. Julie Nemer for her thoughtful suggestion for my final work.

Special thanks to Mr. Phillip Colombo who generously offered his time editing my work.

I am sincere grateful to my informants for spending their precious time to participate in the interviews and share their life experiences with me.

I thank my wife, Michelle, whose understanding and support helped me to go through my graduate studies at Portland State University. 
TABLE OF CONTENTS

PAGE

ACKNOWLEDGEMENTS ........................ ii

LISTS OF TABLES...................... v

CHAPTER

I $\quad$ INTRODUCTION $\ldots \ldots \ldots \ldots \ldots \ldots \ldots \ldots \ldots \ldots \ldots$

II METHODOLOGY AND DATA COLLECTION.......... 18

Historical and Government

Documents.................. 18

Informants and the Questionnaire...... 19

Participant Observation........... 22

Informants' Descriptions.......... 23

III THE CHINESE MIGRATION WAVES............ 26

Three Migration Waves............. 26

Differences Between Hong Kong Chinese

Americans and the Long Time

Chinese Immigrants from

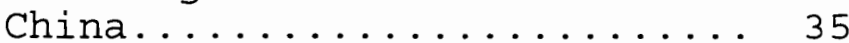

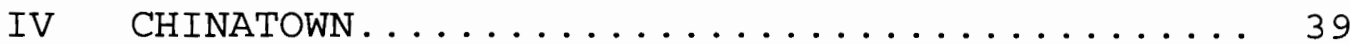

Chinese Organizations............ 45

Clan Associations

Tongs

Huiguans and the CCBA

Chinese in Oregon............... 50 
Hong Kong Chinese Impressions of and Relationships with

Portland's Chinatown........... 56

Chinagate

Chinese Food

Atmosphere of Portland's

Chinatown

V HONG KONG CHINESE AMERICAN IDENTITY........ 62

The story of wong..................62 62

Discussion of Hong Kong Chinese

American Culture Traits......... 66

Speaking Cantonese

Knowledge of Chinese

History

Filial Piety

Ways of Preparing

Chinese food

Observing Chinese Festivals

Place of Birth

Reading Chinese

Books/Magazines

Speaking Mandarin

Clothing

Ancestor worship

Culture Change and

Practice Theory

Situational Changes of Cultural

Identity Among Hong Kong

Chinese Americans............ 87

VI CONCLUSION ...................... 93

APPENDICES

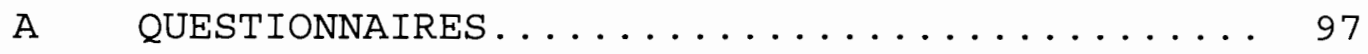

B INFORMANTS' PERSONAL BACKGROUNDS .......... 102

C ASSESSING THE NUMBER OF HONG KONG

CHINESE IN PORTLAND.............. 104

D PERCENTAGE OF CANTONESE AND ENGLISH

USED BY INFORMANTS.............. 107

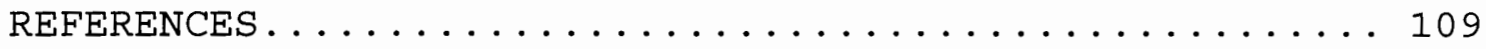




\section{LIST OF TABLES}

TABLE

PAGE

1 Description of the Informants.......... 24

2 Hong Kong Chinese Americans Views of

Ten Cultural Traits............. 67

3 Percentage of Cantonese Spoken in

Everyday Life................ 68 
CHAPTER I

INTRODUCTION

People know what they do; they frequently

know why they do what they do; but what

they don't know is what what they do does.

- -Foucault

My first experience with dim-sum ${ }^{1}$ in Portland, Oregon, four years ago shaped the questions I will investigate in this thesis. It is a common practice for Hong Kong Chinese to have dim-sum on a daily basis, and I never envisioned that anything unusual would happen. However, my experience in this little Chinatown became deeply imprinted on my mind.

Shortly after I arrived in Portland, my friend, John, invited me to have dim-sum with his family. He and his wife were from Hong Kong and had been living in Portland for fifteen years. Their children were born in the U.S. and were all under ten years old. His children could speak some Cantonese but they often mixed it with English.

To my surprise, I noticed that they used forks which made me wonder why John had not taught them to use chopsticks. I was further shocked when the dim-sum were

1 Dim-sum is a Chinese pastry, commonly found in the Southern part of China and Hong Kong. It is usually served with Chinese tea in the morning in Chinese restaurants. 
served. As I raised my chopsticks and prepared to take some dim-sum, his children rushed to their favorite dishes and took the whole plate of food with them.

I was totally stunned by their behavior, and felt perplexed as to why John had not taught them to behave in a "proper" way. The whole scenario bothered me and I spoke very little during the breakfast. Somehow, John realized what had gone "wrong" and said to me "they are Americans," with an embarrassed smile.

On another occasion, I was at his house, and he had just received a wedding banquet invitation from a relative. As soon as he saw the card, he started complaining about the white color of the card, saying that if the couple didn't know, their parents should have known about that. He had a very strong reaction to it and kept saying he would not attend the wedding banquet if they did not change the color of the card to red.

Both incidents made me feel uncomfortable but aroused my interest in understanding them. The behavior that I observed during the dim-sum breakfast contradicted my preconceptions of how John and his children would act. The children did not greet us before they ate (to pay respect), and instead of sharing the dim-sum, which is common practice in Hong Kong, they took the whole plate with them. What shocked me most was that John did not stop them from doing that. 
The second incident revealed that John still saw the traditional ways of preparing a wedding banquet as important and necessary and was upset about his relatives' inappropriate act in sending out white invitation cards instead of red.

I realized that my attitudes and expectations towards some of the traditional Chinese practices were different from John's. Although John and I came from the same place, some of his practices are unintelligible to me. On one hand, he could accept the non-traditional Chinese ways of raising his children, but on the other, he utterly criticized the new ways of preparing a wedding. The incidents seemed to suggest that he felt comfortable with some changes in his practices but insisted on sticking to traditional ways of doing things in others.

Both incidents left me with questions of why John, whom I have known for over fifteen years, had changed that much. After a few years in Portland, I had more opportunities to interact with other Hong Kong Chinese immigrants. It became apparent that some of their practices were different from what I had known in Hong Kong. This again, aroused my interest in understanding this group of immigrants.

John and other Hong Kong Chinese immigrants labeled themselves "Hong Kong Chinese" and emphasized that they were different from other non-Hong Kong Chinese immigrants. If this were the case, it would be reflected in the cultural 
traits that they drew on and in their practices as well. Exactly how John and other Hong Kong Chinese immigrants have come to understand their behaviors in terms of this Hong Kong Chinese identity is the question I wish to pursue.

This research focuses on the study of the cultural identities of a group of Hong Kong Chinese immigrants who have come to reside in Portland, Oregon, U.S.A. in the last twenty-five years. I am interested in knowing what it means for them to be Chinese in Portland, Oregon. What are the different components that constitute their Chinese identity? How have these components changed? In what ways do they recognize commonalities among themselves as "Hong Kong Chinese" or "Hong Kong People?"

Most of the studies of the American Chinese have focused on areas such as Chinese history in America, the legal status of the Chinese in the U.S., and their hardships in America (Kung 1973; Kwong 1987). Other studies have included research on the everyday life of Chinese and the activities of Chinese associations inside Chinatown (Nee and Nee 1972), or the recent developments among a group of Taiwan immigrants in contemporary New York (Chen 1992). There also have been a few studies of the cultural identities of Chinese Americans. These have included research on the panethnic identity movement of Asian Americans (Trottier 1981), and the representation of ethnic identity by Chinese Americans in a northern Chicago 
Chinatown (Ma Qi 1991). Research on Portland's Chinese has been limited to a handful of studies including the statistical comparison of Chinese demographics, occupations, and population in counties in Oregon (Scott 1977), and the history of mutual support organizations among the Chinese in Portland (Manchester 1978).

Since the number of Hong Kong Chinese immigrants has been of no significance until recent decades, very little research has focused on them. However, as the U.S. immigration quota for this group of Chinese jumped in the mid $1980^{\prime} \mathrm{s}$, and with the surging economy of Hong Kong, they have drawn more public attention and have begun to have more influence in the Chinatowns and the Chinese communities in the U.S. My research will build on the previous studies of American Chinese and focus on the cultural identities of the group of Hong Kong Chinese immigrants in Portland.

Studies of minority groups in the U.S. have changed in focus over time. A conventional concept of assimilation coined by Warner (Warner 1945) suggested that minority groups which migrated into a majority society would be totally assimilated. However, the life of the early Chinese immigrants in the U.S., who congregated in Chinatowns, contradicted such a notion. This group of Chinese retained many of their old customs and traditional ways of life and did not reflect much of the American lifestyle. They believed that they did not need any support from the larger 
society but stayed inside Chinatown and relied on the support of Chinese clan, family and community associations. The second- and third-generation Chinese who received American education had more exposure to American culture. Although their chances of assimilation were higher, their assimilation still depended on how they had been influenced by their families when they were being reared.

More recent writings on the theory of assimilation have suggested that some aspects of people's behaviors change faster than the others, and that people will retain some traits of the society from which they came. "The adoption by immigrants of majority practices may give an appearance of change but underlying values may not have altered," (Banton 1981:35). Therefore, minority groups will not necessarily become totally assimilated. For example, Chinese might learn English to communicate with Americans, but might continue speaking Chinese at home, or they might switch to other food choices without altering their own ways of preparing foods.

During the 1970s the study of minority groups turned from models of assimilation to models of ethnicity. Many anthropologists focused on the political nature of the issue of ethnicity. Among the chief proponents of this type of analysis was Fredrik Barth who suggested that people consciously form ethnic groups to pursue their political interests (Barth 1969). Barth asserted that ethnic groups 
were politically organized units which emphasized particular cultural traits in order to highlight their differences with other groups. Such approaches saw the attachment to a certain ethnic identity as the manipulation of culture by a particular group to meet the needs of collective political or economic interests, especially when they were away from their customary and usual way of dealing with things. Thus, the formation of ethnic groups was seen as having mainly to do with the pursuit of collective material needs.

About the same period, anthropological studies also turned to investigate the phenomenon of situational ethnicity (Nagata 1974; Barth 1969). Nagata pointed out that it is possible for some individuals to move freely from one ethnic group to another, even though there exist stable ethnic group structures and ethnic boundaries. For example, a Malay in Singapore might identify herself as Arab when others comment on her energy and industry for preparing the celebration of the fasting month. She would temporarily drop her Malay identity which carries a "lazy" label in that situation. This type of switching did not affect any changes in the structures and boundaries of ethnic categories. Individuals oscillating between categories might not produce any role conflicts or confusion in identities among them. This approach did not suggest an unbounded free movement between categories and individuals, but saw the changes as dependent on different situations. 
According to Nagata, three major factors influenced the situational changes of ethnic identity. The first one was social solidarity and distance. According to this idea, individuals might switch to become members of another category in order to gain social solidarity and keep distance from undesired identities. The second factor was expediency, whereby individuals might change their ethnic selection to gain advantage in matters or resources. The third factor was social status and social mobility, a factor considered the most important by her. This factor stressed the relative social status of different ethnic groups and the actions taken by a particular individual to achieve social status (Nagata 1974:340-344).

The formation of ethnic groups and ethnic identities based on political and economic interests was labeled as the instrumentalist approach and was in turn questioned by other anthropologists (Geertz 1963; Keyes 1976). Focusing on the emotional aspect of ethnic group formation, they initiated a wide discussion of primordial attachments within ethnic groups. These anthropologists contended that a deeplyrooted sentiment based on a common heritage among individuals drew them together. Such a group became a refuge for its members, who sought emotional sustenance because they had lost their orientation after having moved to a different environment. While this primordialist model might provide some insights into understanding the closeness 
of the group of Hong Kong Chinese immigrants, it fails to explain how Hong Kong Chinese came to the realization of such collective sameness. Although the political and primordial explanations as aspects of ethnicity should not be overlooked, Bentley (1987) has more recently argued that attention must also be paid to other aspects of cultural identity, most notably the question of the impact of prior experience. This approach draws on Bourdieu's theory of practice and the concept of habitus (Bourdieu 1977) to provide a more thorough explanation of how ethnic identity develops within individuals and groups.

According to Bourdieu's practice theory and the concept of habitus, similar practices among individuals provide them with a sense of likeness and a feeling of commonality. Practices are shaped by the habits developed during an individuals' past experiences. These shared habits can in turn lead to a feeling of commonality among people with similar past experiences, thus, explaining why people come to label themselves with particular identities. For example, my friend John's behaviors can be interpreted by applying practice theory and the concept of habitus. The choice of color is one of the most important aspects in preparing traditional Chinese celebrations or ceremonies. Red is an auspicious color used in all celebratory occasions including wedding banquets, while white is traditionally associated with death and funerals. This belief is not easy 
eroded, even after Chinese have moved to other western countries. John and his relatives' practices are shaped by their past experiences in Hong Kong. He expected his relatives to perform the same practice as he did. But when he found out his relatives could not live up to the expected standard, he was very upset about it. It would seem that in his mind, the correct use of red is an important symbol for a Chinese identity.

On the other hand, John treated his children differently. His children were reared under a different habitus scheme. Even though he might have tried to influence or inculcate his children in terms of what he had experienced in the past, for example, teaching them how to use chopsticks, he could not expect his childrens' practices to be the same as his. Indeed, his children had more chances to use forks than chopsticks and spent more time interacting with Americans and the larger society. This did not imply that John had no control over his childrens' practices, rather, it might reflect John somehow had made a choice of not forcing his children to keep using chopsticks. Maybe he believed that such a practice was an unimportant trait for a Chinese identity. After all, their formative experiences were different, and John had to live with his children's practices. John's and his relatives' common ground underlined who they were, while highlighting the differences between him and his children. 
Practice theory and the concept of habitus are complicated and dense. It is impossible to summarize Bourdieu's ideas in only a few sentences. Therefore, I will concentrate on extracting and highlighting ideas that are important to illustrate the formation of ethnic identities, and will then seek to apply them to the study of the group of Hong Kong Chinese Americans.

Practice theory and the concept of habitus carry some distinctive elements. First, habitus is a system of "durable, transposable dispositions" (Bourdieu 1977:72) which is the product of inculcation rooted in the early life of individuals. Early experiences are proportionally weighted heavier than later experiences in shaping people's practices, and such experiences are mediated through family in an individual's early life. Examples might include the sexual division of labor, domestic morality, cares, strife, tastes, etc. (Bourdieu 1977:78). These experiences become "the basis of perception and appreciation of all subsequent experience" (Bourdieu 1977:78).

Second, the practices produced by habitus are unconscious.

The very intimacy of the experience, which is nothing but common memories that have become unconscious [emphasis add] excludes the possibility of cutting a tie that was formed, not alone by the same blood, but by the same rhythm of living (Theodor Reik, quoted in Epstein 1978:140). 
Thus, the nature of habitus is grounded in "common memories that have been unconscious," and this unconscious part is incorporated in a person's life.

The 'unconscious' is never anything other than the forgetting of history which history itself produces by incorporating the objective structures it produces in the second natures of habitus (Bourdieu 1977:78-79).2

Third, the practices produced by habitus are performed without aiming towards a particular end. Experiences are unconsciously rooted in people's lives and people's daily practices do not necessary have a predetermined intention of achieving specific goals. For example, Hong Kong Chinese have not emphasized their Chinese identity when interacting with the wider society in order to gain economic advantages. Practices are not just static responses or mechanical reactions to obtain certain expected results, but they may unconsciously change in response to a new environment, which may in turn affect habitus.

2 Detailed elaboration of the unconscious part of habitus is provided by Epstein, "...in each of us, in varying proportions, there is part of yesterday's man; it is yesterday's man who inevitably predominates in us, since the present amounts to little compared with the long past in the course of which we were formed and from which we result. Yet we do not sense this man of the past, because he is inveterate in us; he makes up the unconscious part of ourselves. Consequently we are led to take no account of him, any more than we take account of his legitimate demands. Conversely, we are very much aware of the most recent attainments of civilization, because, being recent, they have not yet had time to settle into our unconscious," (E. Durkheim, quote in Bourdieu 1977:33). 
This notion of change raises another important aspect of practice theory and the concept of habitus: its capacity to "reproduce" itself. As people's practices are shaped by their past experiences or habitus, habitus will also continually change and regenerate anew within the context of practices. "Change in objective conditions and consequent life experiences generate changes in structures of habitus subsequently produced" (Bourdieu 1977:33). Therefore, not only are our practices shaped by the unconscious habitus, but habitus will respond and change when situations change. The application of the notion of habitus to the construction of ethnic identities exhibits fundamental differences from the views of instrumentalists and primordialists and adds a new perspective to the study of ethnicity. Unlike instrumentalist approaches, practice theory avoids the assumption that the outcomes or consequences of ethnic group behaviors are the cause of the formation of ethnic groups. The notion of "reproduction" emphasized by Bourdieu is also clearly different from the ideas advanced by the primordialists. The primordialists view people as emotionally attached to a traditional past which is not subject to change. Based on this premise, they emphasize an individual's emotional need to seek refuge in a new and disoriented environment, with the emotional tie to an unchanging tradition explaining the formation of ethnic groups. According to Bourdieu's practice theory and concept 
of habitus, individuals act and behave unconsciously in a changing environment based upon experiences previously ingrained in their minds. People's sensations of ethnic affinities are founded on their common life experiences, and the similar dispositions they share are generated by habitus. This sense of being like each other reenforces a cohesion of the group based on the commonality of experience and the unconscious habitus it generates. Thus, a sense of sharing a common identity arises among these individuals and defines who they are.

It is, therefore, the same "rhythm of living" among the group of Hong Kong Chinese Americans that defines their identity. By investigating different aspects of their shared experience and their practices in the U.S, we are able to have a better understanding of this group of people. The application of practice theory and the concept of habitus is not only effective in dealing with individual identity, but with group identity as well. The ethnic identity of a group is mostly used for the investigation of social collective actions. Bourdieu (1977:191) has pointed out that ethnicity can be viewed as a fictive kinship which carries a sense of enduring solidarity and obligations among members of a group in order to enhance its cohesiveness.

However, my study of Hong Kong Chinese American identity in portland has come to focus on individuals rather than groups. Several reasons explain my approach. 
Throughout my research in the last year, I encountered no collective actions arranged by this group of immigrants; thus, there is a good possibility that collective actions are unlikely to be found among them. The Hong Kong Chinese population in Portland is small, and it is dispersed within the wider society. Activities among them are usually arranged on an individual basis, so that no specific Hong Kong Chinese group activities are found in Chinatown or other areas in Portland. However, in other larger cities such as Vancouver, B.C., San Francisco and Los Angeles where larger Hong Kong Chinese populations are found, it might be possible to study the group identities of Hong Kong Chinese immigrants .

Practice theory and the concept of habitus do not preclude instrumentalist or primordialist views but emphasize that ethnic identity is best understood by reference to people's shared experiences. Thus, the use of ethnic symbols by individuals does not have to be merely a manipulation to meet the political, economic, or emotional needs of individuals.

It is the differences in habitus that accounts for differences between Hong Kong Chinese and other non-Hong Kong Chinese Americans. The term "Hong Kong Chinese" or "Hong Kong People" thus carries important meanings for the group of Hong Kong Chinese immigrants who came from the same place. 
The following chapters will trace the characteristics and changes of ethnic identity of Hong Kong Chinese Americans in Portland. Chapter two provides a detailed discussion of how my research was conducted and how the data were collected. In addition, a brief description of the personal background of the twenty-eight informants is presented.

Historical context is important to show where Chinese Americans have come from and how they have changed through time. Chapter three explores the characteristics of three Chinese migration waves in the last hundred years; the Chinese Americans' relationship with the U.S.; the survival of the Chinese in the U.S.; and their recent development. The historical background provides a contrast between the long time Chinese settlers in Portland and the Hong Kong Chinese who have come in the last ten years. Their past experiences shape what they practice today and explain why they differ from each other.

Chapter four depicts the formation of Chinatown; its characteristics; its organizations, such as the Chinese Consolidated Benevolent Association (CCBA), district associations, clan associations and tongs; Chinese life inside Chinatown; and Hong Kong Chinese views of Portland's Chinatown and their relationships with it. This chapter provides contextual information for the analysis of different perceptions of Chinatown among Hong Kong Chinese. 
Chapter five focuses on the discussion and analysis of the cultural traits that distinguish Hong Kong Chinese Americans from other non-Hong Kong Chinese Americans, and asks how their identities have changed since coming to reside in the U.S. It further explores what has caused such changes, and how an individual's ethnic identity might change as situational changes occur.

Chapter six summarizes my findings concerning the key components of Hong Kong Chinese Americans identity, the changes in those components, and the usefulness of practice theory and the concept of habitus in understanding ethnic identity changes. 


\section{Chapter II}

\section{METHODOLOGY AND DATA COLLECTION}

This research was based on three main sources: 1) historical and government documents, 2) formal interviews of Hong Kong Chinese, and 3) participant observation. This chapter will discuss each source in detail. The final section presents the personal backgrounds of the twentyeight informants who answered more structured questionnaires.

\section{HISTORICAL AND GOVERNMENT DOCUMENTS}

Information on the historical background of the early Chinese immigrants in the U.S.; the development and organization of Chinatowns; and the demographic background, education and occupations of the Hong Kong Chinese was drawn from the records and documents available from the Oregon Historical Society, the Chinese Consolidated Benevolent Association, the Chinese Language School, the U.S. population census and other written materials (Chen 1980; Tsai 1986; Kung 1973). The historical context highlights the differences between Hong Kong Chinese and Chinese from other areas. 
INFORMANTS AND THE QUESTIONNAIRE

In order to obtain information about the Hong Kong Chinese perception of Portland's Chinatown, their viewpoints of the traits that constituted their Chinese identities, and their lifestyle in the United States, a questionnaire was prepared and formal interviews were conducted with twentyeight informants. These people were recruited through networking and through introductions from Chinese friends and prominent Chinese in Portland's Chinatown. A few were contacted by me directly when I visited the Chinese Language School in Chinatown, Chinese restaurants, Chinese churches and recreational centers in the Portland area.

The questionnaire was divided into five sections. 1) the informant's personal background; 2) the cultural traits they felt exemplified their Chineseness; 3) their impressions of Chinatown; 4) their religious beliefs; and 5) questions about their workplace, home and activities. An appointment was set up with the informants prior to any formal interviews. Informants were notified of the purpose of the research and they all consented to the interviews. After the first few interviews, I found that some questions of crucial importance to the research were missing, such as the informants' perceptions of other Hong Kong Chinese in Portland, and their perceptions of other Chinese from Taiwan and Mainland China. Therefore, the questionnaire was revised and a few questions were added (see Appendix A). 
The questionnaire was prepared in both English and Chinese. The interviews were conducted in Cantonese. Since the Chinese from Hong Kong mainly speak Cantonese, a dialect widely spoken in southeast China, I found that it was appropriate and direct to conduct the interviews in their own language. The data collected were recorded in Chinese and later translated into English for analysis.

I chose Hong Kong Chinese immigrants as the subject of this study for two reasons: first, because of my general interest in the study of Chinese culture, and in particular, how different groups of Chinese have changed after they migrated to the United States. Second, although Chinese have come from three major areas (Mainland China, Taiwan, and Hong Kong), the time scale of this research limited the focus to one group of Chinese immigrants. Being a Chinese from Hong Kong, I was particularly interested in knowing how well this group of Chinese performed in the United States and how they realized a sense of togetherness among themselves.

Establishing trust with Chinese and requesting an interview are not easy tasks, especially when one is a stranger to them, a notion which prevails in China and Hong Kong as well as in the U.S. Nevertheless, attitudes towards strangers are not as tense in Portland as in Hong Kong. As May, one of my informants expressed it: "there are already a very small population of Hong Kong Chinese in Portland, and 
we should be glad that we have the opportunity to know each other and live in the same place. We should feel closer to and familiar with each other." Her claim might explain the reduction of hostility among Portland Hong Kong Chinese towards another Hong Kong Chinese who is a stranger. However, building up some kind of relationship with informants was still necessary before requesting an interview. They needed to have confidence in me.

Although not born in China, many of the Portland Hong Kong Chinese informants are of Toishan descent. Fortunately, my wife is of Toishan descent and her family has been in Portland for a long time. Referring to matters relating to their knowledge of Toishan helped to lessen the sense of strangeness between informants and myself when conducting the interviews. In addition, because the Chinese community in Portland is small, it is not unusual within a few conversations for people to recognize links with each other: someone might be the relative of someone, or their parents simply came from the same village, etc. Thus, I was able to build up a good relationship with some of the informants by referring to my wife's family members and other prominent Chinese I had met in the Chinese community. Hence, by using a common language and establishing a shared relationship with the informants, the interviews were much easier than anticipated. 
The opportunity to interact with Portland Hong Kong Chinese on a more intimate and personal level was advantageous to me as an "insider", reducing the many months in the field anthropologists often need in order to gain sufficient trust from informants to conduct formal interviews. However, I also considered myself an outsider and a new learner, because I did not know much about the life of either the long time Chinese immigrants or the more recent Hong Kong Chinese immigrants. I knew I had a lot to learn from them.

\section{PARTICIPANT OBSERVATION}

Besides relying on questionnaires, I visited Chinese churches, the Chinese Language School, shops inside Chinatown, Chinese restaurants, and some recreational centers where Hong Kong Chinese like to go. I also participated in and observed various activities such as a clan association annual dinner, picnics and the lion dance. I talked to Chinese informally about their impressions of Portland's Chinatown; other Hong Kong Chinese; their changes since moving to the United States; and their activities. Sometimes, I just simply observed how Hong Kong Chinese interacted with each other or with other Americans, or just listened to their conversations and observed their behaviors. The interaction with Portland Chinese and the observation of their daily activities widened my scope of 
understanding about how Chinese reacted in different situations and how their individual identities changed when scenarios around them changed. These provided significant examples of how people shifted their identities and what traits were important to them.

\section{INFORMANTS' DESCRIPTIONS}

Twenty-eight informants were chosen for more formal interviews. The questions were aimed at providing an understanding of how Chinese identities changed and how their sense of commonality came about.

The interviews were conducted from May 1992 to November 1992. Table 1 describes the sex, age, occupation, and education of the twenty-eight informants. Fourteen females and fourteen males were selected for interviews. Their ages ranged from twenty-one to fifty plus years old, with an average age of thirty-six. Seventy-five percent of my informants were aged between thirty and forty-nine. Seven informants had a high school education, seventeen had university degrees, and two had graduate degrees, thus, reflecting a group of educated people, common among any group of Hong Kong immigrants. The occupations of my informants fell into two main categories, managerial and professional, which corresponds with their educational background. 


\begin{tabular}{|c|c|c|}
\hline & Number & Percentage \\
\hline \multicolumn{3}{|l|}{ Sex } \\
\hline Male & 14 & 50 \\
\hline Female & 14 & 50 \\
\hline \multicolumn{3}{|l|}{ Age } \\
\hline $20-29$ & 5 & 18 \\
\hline $30-39$ & 14 & 50 \\
\hline $40-49$ & 7 & 25 \\
\hline 50 +over & 2 & 7 \\
\hline \multicolumn{3}{|l|}{ Occupation } \\
\hline Clerical & 6 & 21 \\
\hline Managerial & 11 & 39 \\
\hline Professional & 6 & 21 \\
\hline student & 3 & 11 \\
\hline Home worker & 1 & 4 \\
\hline Retired & 1 & 4 \\
\hline \multicolumn{3}{|l|}{ Education } \\
\hline High school graduate & 7 & 25 \\
\hline Some college & 2 & 7 \\
\hline 4-year college degree & 17 & 61 \\
\hline Post-graduate degree & 2 & 7 \\
\hline
\end{tabular}

Table 1. Description of the informants ( $N=28)$

Twenty of my informants had been born in Hong Kong, and the minimum number of years they had lived in Hong Kong was ten. Thirteen of them had lived less than ten years in the U.S. Among the twenty-eight informants, twenty-two were married, out of which seventeen had children, and eleven of them had children born in the U.S.

All of the informants spoke Cantonese and English. Although three claimed that they did not know any English, their educational background indicated that they should have had some knowledge of English. Their denial of English 
ability might have reflected their lack of English conversation practice and a fear of revealing that they knew English. (For informant by informant information, see Appendix B) . 
Chapter III

\section{THE CHINESE MIGRATION WAVES}

\section{THREE MIGRATION WAVES}

During the last hundred years, three significant migration waves of Chinese immigrants arrived in the U.S. The first large-scale movement of Chinese immigrants began in the mid-nineteenth century and derived from three main factors. First, a combination of the Taiping rebellion, natural disasters in China, and disastrous foreign wars inflicted great hardship on the Chinese masses (Chen 1980; Tsai 1986). Second, the lure of gold mining and railroad construction attracted Chinese to leave their homeland in order to find opportunities to provide financial help for their families in China. Third, the need for cheap labor for the building of the transcontinental railroad made the mass importation of Chinese laborers possible. The motive of the movement suggested by these factors was mainly economic: the Chinese hoped to earn money overseas in order to eventually better their lives and their families' lives in China. These Chinese sojourners planned to return to their hometown as soon as they were able to adequately support their families in China. 
Victor and Brett Nee in their book Longtime Californ', depicted the experience of Chinese immigrants in America, based on interviews with chinese in San Francisco's Chinatown. Two of their informants revealed their reasons for coming to the U.S.

There were hard times in the village when a harvest was bad. The whole season's crop would barely fill the bushels of rice they owed for rent. In the village, you were always trying to live on nothing. Cut down on meat, that was the only way we could get by. (Nee and Nee 1972:16).

From one generation to another, everybody tried to send a man overseas. That's the only way you can make things better.

(Nee and Nee 1972:17).

This first group of early immigrants were largely uneducated poor peasants who came from villages in the rural area of Southeastern China. About $60 \%$ of them were natives of the two districts of Toi-Shan and Hsing-Ning in Guangdong Province (Tsai 1986:96-97), and Toishan dialect became the language most commonly spoken by the early Chinese immigrants. At the turn of the century, almost all of the Chinese immigrants were male, some with wives and children in China but most of them still single.

Four reasons accounted for the male dominant Chinese society in the U.S. at that time. First, traditionally, the Chinese family was patriarchal and patrilineal with inheritance passed through the male line. In general, there was a division of labor between Chinese males and females where the women took care of the domestic sphere while the 
men were involved in the public sphere. Women stayed at home to take care of the children and the parents-in-law, and to provide labor in the house for the family. Males were responsible for work outside, making contacts with the larger society, and supporting the family financially. Therefore, when the family encountered difficulties, it was the male member who went overseas to look for opportunities and the females who stayed at home to take care of family matters. Second, wives of Chinese laborers were forbidden to enter the U.S., except for the wives of Chinese merchants and diplomats. Third, in 1884, the anti-miscegenation law was passed, prohibiting intermarriage between Chinese men and white females. Fourth, the hostile environment and the unknown future of their lives in the unfamiliar country made the Chinese hesitate to bring their wives along with them, even before the enactment of the prohibition on the entry of Chinese laborers' wives. Therefore, it is not surprising that the male to female ratio of Chinese in the U.S. in 1910 was 14:1 (Kung 1973:33). The Chinese female population was mainly composed of a small number of native-born women, wives of merchants, and imported prostitutes (Manchester 1978:42; Nee and Nee 1972:62).

The single Chinese men were lonely and had a strong desire to return home as soon as possible. The small numbers of Chinese women in the U.S. Iimited the chances for the Chinese to settle down and form families which they 
needed to do in order to maintain their ancestral line. In Confucian philosophy, men had a responsibility to continue the family line, and to live without bearing sons was regarded as one of the practices that offended the notion of filial piety. Chi-lien Chen's translation of twenty-four letters written by a Chinese miner's family in China at the turn of the century expressed their eagerness to persuade their family members to return to China. The need to have a son was explicitly revealed in the letter,

Come home as soon as you can. Don't say 'no' to me any more. There are too many gossips in our village that make me uneasy. You are my only son. You have no brothers, and your age is near forty but still without a male offspring. You should think carefully. If you neither make a fortune abroad nor have a son at home, your loss is double. So why not come home before it is too late? (Chen 1972:145).

Chinatowns developed to accommodate these bachelors and to provide aid and protection for them. The role of Chinatown became more important and influential especially after the passing of the Exclusion Acts. In the 1870s, after the completion of the transcontinental railroad and the depletion of gold mining, many Chinese laborers began to look for other jobs. The hostility towards the Chinese began in California as a result of a changing economic situation and the political opportunism of the politicians in the state. On the one hand, severe unemployment among white Americans and the cheap labor provided by Chinese explained the anti-Chinese sentiments. On the other hand, 
the politicians who depended upon the working class voters stirred up popular feeling against the Chinese so as to fulfill their political ambition. Californian politicians pushed very hard to pass the anti-Chinese Act in the state and further the fight for a national Chinese exclusion bill (Nee and Nee 1972:49).

This began a series of anti-Chinese legislative acts by the U.S. government prohibiting the entry of Chinese laborers. The first discriminatory act, the Chinese Exclusion Act of 1882, restricted skilled and unskilled Chinese workers from coming to the U.S. for ten years. Chinese workers who had already been in the country were not allowed to bring their families from China. The Act also required the Chinese to carry registration certificates and valid passports when leaving or entering the U.S. However, teachers, merchants, students, and diplomats were allowed to continue to enter the country but under scrutiny of the authorities (Kung 1973; Chen 1980).

Even before the act was passed, hostile actions were often reported by Chinese immigrants in San Francisco. Chinese children were afraid to walk outside Chinatown alone, because they were chased and stoned by Caucasian Americans. The Exclusion Act sent an unwelcome message to the Chinese community and further fired up the sentiments of Caucasian Americans, leading to more violence, segregation and discrimination against Chinese throughout the United 
States. Anti-Chinese violence began in Rock Springs, Wyoming, in 1885 when twenty-five Chinese miners were killed. Other riots spread to Washington, California, Idaho, and Oregon (Kung 1973; Chen 1980; Tsai 1986). The consequences of these discriminatory acts and the violence against Chinese resulted in the segregation of Chinese inside Chinatowns. Furthermore, many Chinese left the country, causing the Chinese population to drop from 107,488 in 1890 to 61,639 in 1920 (Kung 1973).

Following the Chinese Exclusion Act of 1882, a number of anti-Chinese Acts were imposed in the next sixty years. In 1884, Chinese laborers were accused of using certificates for teachers and merchants to gain entry to the U.S., or making their ways into the U.S. via countries other than China. In response to these Chinese activities, the U.S. government restricted all new Chinese workers from entering "any and every port" (Chen 1980:154). In 1888, the Scott Act further prohibited Chinese workers who held legal reentry permits from reentering the U.S. after a temporary departure. A detention center was also established on Angel Island in San Francisco Bay where Chinese merchants and students were detained for a legal identity check, so as to verify they were not Chinese workers. They could be kept there for as long as two years. One of the poems carved on the wall of the center reflected the sentiments of these immigrant prisoners. 
Why do I have to languish in this jail?

It is because my country is weak and my family poor.

My parents wait in vain for news;

My wife and child wrapped in their quilt, sigh with loneliness.

Even if I am allowed to enter this country.

When can I earn enough to return to China?

since ancient times, most of those who

leave their homes have not been worth a damn.

Up to now how many have ever returned

triumphant from this battle?

(Chen 1980:188).

The Geary Act of 1892 extended the ban on the

immigration of Chinese laborers for ten years. Between 1906 to 1924, an average of 150 Chinese women per year entered the U.S., and Chinatown began to slowly change from a bachelor to a family-oriented society. However, the second Exclusion Act of 1924 exerted a numerical restriction on immigration to the United States from all parts of the world except the Western Hemisphere. Under this Act, from 1924 to 1930, no Chinese women were entitled to enter the United States, and this slowed down the growth of Chinese families and further reduced the birth rate of American born Chinese. In 1930, $80 \%$ of the American Chinese population was composed of males, and Chinatown was still largely a bachelor society (Kung 1973). Aftex the act was revised in 1930, sixty Chinese women were allowed to enter the U.S. per year, and this again provided some limited opportunities for Chinese to build their families, (Nee and Nee 1972).

The American attitude towards Chinese changed during World War II, when China was seen as an American ally in the 
fight against the Japanese. The Exclusion Acts were repealed in 1943 as a result of the normalization of the relationship between the two countries (Chen 1980:206). Under the Magnuson Act, Chinese were allowed to become naturalized citizens, and the annual quota for Chinese immigrants was increased to 105 (Chen 1980:211).

The second wave of Chinese immigration began after the abolition of the discriminatory and anti-Chinese immigration quota system in 1965. These great changes had their roots in the 1950s and the civil rights movement led by black society which focused on opposing racism and discrimination against all minority groups (Chen 1980:216). Consequently, a number of acts were signed in response to this mass movement. In 1954, the U.S. Supreme Count acted against school segregation, and in 1964, a Civil Rights Act was signed by President Johnson to ban segregation in all public facilities and in the trade unions. These acts laid the foundation for the Immigration Act of 1965. Under the new laws, each foreign country was subjected to an annual numerical limitation of 20,000 visas (Chen 1980:216). This resulted in a significant increase in Chinese immigrants. The once lopsided gender proportions changed dramatically, and the ratio of male to female of all Chinese in the U.S. dropped to 1.07:1 (Tsai 1986). During the same period, the numbers of Taiwan and Hong Kong Chinese students who studied in the U.S. also increased. 
The third wave of Chinese immigration into the U.S. appeared after 1986. Prior to 1986, only 500 visas were issued each year to people born in Hong Kong because of its dependent colony status. In 1986, the quota for dependent colonies was increased to 5,000. This sped up the usual long waiting period for would-be Hong Kong Chinese immigrants. The Immigration Act of 1990 reclassified Hong Kong as a separate country, allowing it seven percent of the worldwide quota, or about 25,000 visas a year after 1993 . In the meantime, Hong Kong people were granted a quota of 10,000 visas in the transitional period. This act promised the continuity of the status for Hong Kong people even after the sovereignty of Hong Kong returned to China in 1997 . (Martha S. Siegel and Laurence A. Canter 1991).

Unlike Chinese sojourners in the 19th Century, the second and third waves of immigrants were no longer so homogeneous but were composed of quite diverse groups of Chinese from Mainland China, Taiwan, and Hong Kong. During the 1960s, a large number of Chinese students from Taiwan sought higher education in the United States, and most remained in the U.S. once their education was completed. The impact of the June fourth Beijing incident in 1989 was also significant both for Mainland Chinese students studying in the U.S. and Chinese in Hong Kong. With a sense of insecurity and a loss of confidence in the future of Hong Kong, increasing numbers of Hong Kong people began to plan 
to move overseas. The enlarged quotas for Hong Kong of the U.S. Immigration Acts of 1986 and 1990, coupled with the unpredictable political future of Hong Kong, encouraged the expanding migration of Hong Kong Chinese overseas. Following Canada and Australia, the U.S. became the third most favorable country for Hong Kong Chinese who sought to migrate in the past few years (Skeldon 1990).

\section{DIFFERENCES BETWEEN HONG KONG CHINESE AMERICANS AND THE LONG TIME CHINESE IMMIGRANTS FROM CHINA}

The Iife experiences, education and economic backgrounds of Hong Kong Chinese Americans were very different from the group of early Chinese immigrants from China. As pointed out in the last section, early Chinese immigrants from Mainland China had experienced peasant life in small towns and villages in China, and they had fewer contacts with westerners before their arrival in the U.S. In contrast, Hong Kong Chinese Americans had Iived in a westernized urban city under British rule and had many opportunities to interact with non-Chinese before they came. They were more educated and had a better command of English, opening up job opportunities not limited to the restaurant business. Furthermore, as suggested by Hong Kong Chinese and some Chinese businessmen in Portland, Hong Kong Chinese had experienced a fast and competitive economic environment in Hong Kong and tended to be more aggressive and open- 
minded in doing business than their predecessors in Portland. In addition, Hong Kong Chinese who migrated in the last twenty years tended to settle in white American neighborhoods, not in Chinatowns, and had no experience of what life had been like in places like Portland's Chinatown. Differences in life experiences were also observed among the group of Hong Kong Chinese Americans as well, based on when they had arrived in the United States. In order to investigate the different practices among Hong Kong Chinese Americans who came to the U.S. over ten years ago in contrast with those who came in the last ten years, two terms are assigned to them: "old Hong Kong Chinese Americans" to represent the former; and "new Hong Kong Chinese Americans" to represent the latter. Financially, the new Hong Kong Chinese immigrants are wealthier, more money-oriented and have a tendency to spend more than their less wealthy and thrifty predecessors. Before the newer arrivals migrated to the U.S., they could afford to visit the city where they intended to live, enabling them to plan ahead and prepare for change. Thus, new Hong Kong Chinese immigrants, in many ways, experienced part of the U.S. lifestyle before they came.

Another important difference between the groups of old and new Hong Kong Chinese immigrants is that the latter like to visit Hong Kong on a frequent basis, usually every year or two enabling them to "update" information about Hong Kong 
and bring back current trends in fashion, entertainment, and other social, political and economic news. However, old Hong Kong Chinese Americans seldom pay any return visits, rendering their daily life practices different from the new Hong Kong Chinese immigrants whose lives are not only shaped by their past experiences in Hong Kong but also by their experiences in the U.S. and their ongoing relationship with Hong Kong.

The differences in life experiences between these Hong Kong Chinese immigrants are mainly a result of the economic changes in Hong Kong in the last decade, when Hong Kong has experienced booming economic growth and rising living standards. Since becoming an international trade center, Hong Kong has attracted investment from all over the world. For example, it is not surprising to see major fast food services found in the U.S. also found in Hong Kong. Therefore, new Hong Kong Chinese have enjoyed more activities introduced to Hong Kong by the western world in the' 80 s than the old Hong Kong Chinese immigrants did in the '60s and '70s.

This chapter has reviewed the historical context of the Chinese immigrants who came into the U.S. in different stages in the last hundred years, and the differences between Hong Kong Chinese immigrants and the early Chinese immigrants from China. Their differences underlie impressions Hong Kong Chinese have of Portland's Chinatown 
and the identity they carry. The next chapter will take a closer look at Chinatowns in the U.S. in general and Portland's Chinatown and activities in particular. 
CHAPTER IV

\section{CHINATOWN}

This chapter focuses on a discussion of Chinatowns and Chinese organizations inside Chinatowns in the U.S. in general and on the development of Portland's Chinatown. Hong Kong Chinese immigrants' impressions of and relationships to Portland's Chinatown are also discussed. This historical context provides valuable information on the differences in life experiences between Hong Kong Chinese Americans and the long time Chinese settlers from Mainland China.

The term "Chinatown" first appeared in 1853 in newspaper reports which referred to the Chinese community in the San Francisco area (Barth 1964:110). The Chinatown of that time was no larger than the towns or workcamps where Chinese laborers stayed for gold mining and railroad construction. The expansion of Chinatowns and the increase in the number of Chinese living in urban areas did not begin until the completion of railroad construction in the 1870s. The early group of Chinese came by steamboat and landed in San Francisco, from where they were sent to work camps in Sacramento, stockton, and other areas. Since they knew little or no English, Chinese workers were hired through 
brokers, and wages were distributed by these brokers at the end of each month. After work, the Chinese stayed in the workcamp where they slept in small tents or on the ground. These workers did not receive any protection from the company and were vulnerable to discriminatory policies. For example, among a number of tax actions that were imposed on the Chinese, the state of Oregon in 1859 required that Chinese miners pay a five dollar poll tax from which the whites were exempted.

When the mining industry showed no further prospects, the Chinese switched their attention towards the transcontinental railroad construction. Nevertheless, working for the railroad company provided no better treatment for the Chinese. Chinese workers received only \$26 to \$35 a month and had to provide their own food and pay housing costs, while white workers received the same payment but were provided with free food and lodging. Furthermore, the Chinese had to participate in the most dangerous part of the work such as setting dynamite on cliffs to solve tunnelling problems. After the completion of the railroads, the Chinese did not receive any praise or recognition from the company in the celebration ceremony and were not allowed to participate in the festivities celebrating the success of the construction. However, the fact that the Chinese were hard working and industrious was well known in the railroad construction business. They were hired to work in other 
projects such as the Southern Pacific Railwork. After the completion of these projects, the Chinese stayed in little towns and worked as cooks and servants for white Americans. Some became self-employed grocers, laundrymen, and barbers (Tsai 1986:19). In California, Chinese workers also participated in agriculture, fishing, shoe manufacture, tobacco production, and navigation. In direct competition with white Americans, the skills and low wages of the Chinese aroused opposition and fomented hostility.

Anti-Chinese attacks became apparent in the late $1870 \mathrm{~s}$ and began in California. Articles of the second constitution of California stipulated that "no Chinese shall be employed on any state, county, municipal, or other public work, except in punishment for crime" (Tsai 1986:57). This article was later declared unconstitutional by the United States Circuit court, but the attitudes and intentions of politicians in general determined the fate of Chinese immigrants in the next sixty years.

After the Exclusion Acts were passed, violence towards the Chinese increased. Those who lived in small towns were driven away by fire, threats, or attacks triggered by the hostile community. Ironically, it was the railroads that they had built which took them back to California. Most of the Chinese went to San Francisco's Chinatown for survival. Although the Iiving conditions were poor, with some forced to live in double-decker beds, and families having to 
squeeze into one room without kitchen or bathroom, they dared not move out of Chinatown. Chinatown became the safest place for them. However, it was hard to find jobs in mainstream work like tobacco production and shoe manufacturing, and most Chinese ended up working as laundrymen and vegetable peddlers inside chinatown. Some could not survive the harsh conditions and committed suicide, and some went back to China. The rest tried to stay and find ways to survive.

During the exclusion period, some Chinese found seasonal jobs on the farms outside San Francisco's Chinatown. In the summers, they worked from farm to farm picking cherries and pears or planting, but they still lived in poverty because they could not save money with such temporary work. The life of the single Chinese inside Chinatown was well reflected by Kam Wai, a farm worker who picked fruit in the San Francisco valley during summer.

During weekends, I could do only two things, I could spend my time in a gambling joint, or I could go around to the prostitution towns...so, as I say, at that time, Iife didn't mean too much for us (Nee and Nee 1972:24).

The Chinese were further affected by the Immigration Act of 1924 which prohibited them from bringing their wives into the U.S. For single Chinese, the miscegenation law prohibited them from marrying white Americans. This segregation also extended to the high school education of their children, with the establishment of an Oriental School 
in Chinatown solely for Chinese, Japanese, and Korean children.

The face of Chinatown changed in the 1920s when the second generation of American Chinese began to emerge. The small businessmen who could bring their wives and children legally into the U.S. under the Exclusion Acts began their family life inside Chinatown. In addition, some Chinese workers were able to bribe wealthier merchants to list them as patrons so as to become eligible to bring in their children. Walls in the tiny rooms were pulled down to accommodate families, and thus began a mixture of bachelor and family lives inside Chinatown. For the small businessmen, family life was integrated with business life because most of their businesses were home-based, and children were used to help out in the family business after school. The family had to work long hours, and activities at night often included a chat with friends or a game of mahjong.

Most parents held the traditional Chinese belief that education was the way to success, and they realized that it was also the way to compete with white society. Therefore, they encouraged and pushed their children to excel in school. When this group of second-generation Chinese grew up and entered higher education in America, they tended to follow the lifestyle ways of their American classmates. This generation exhibited significant differences from their 
parents such as preferring American food, using more English than Chinese, and dropping their Eolk religious practices. Although they were able to receive an education in the U.S., however, it was often not easy for them to find jobs after they graduated, both because they were Chinese and because of the U.S. depression in the 1930s.

It was not until world War II that relations between China and the U.S. became normalized, making the entry of new Chinese immigrants possible. May Low, who was Iiving in a village with her mother in Canton, was able to join her father in San Francisco after WWII, and remembered their meeting thus:
Until I was twelve years old, I never saw my father. I just knew the pictures he had been sending all along. In 1945, when I was twelve, we left the village and went to Hong Kong. Then all of a sudden, one day my mother told us we were going down to the pier to pick up our father....then when he said he was going to bring us over to America, I think that was the best news I had ever heard since I was born (Nee and Nee 1972:173).

The separation of Chinese family members dating from the exclusion period came to an end, and there began a slow migration of Chinese women into the U.S. Chinatown began to develop into a family society.

Second and third generation American Chinese began to move out of Chinatown after they received better educations and had a better chance to work in the larger society. However, for those who did not know any English, Chinatown was still the only place for survival. In fact, besides the 
illegal immigrants, there was a steady inflow of Chinese immigrants from China and Hong Kong in the 1960 s who also relied on the support of Chinatown. This was a place which more closely resembled their daily world in Hong Kong and China. Chinatown provided the new immigrants with both jobs and a familiar environment which eased their adjustment to the new society. For these reasons Chinatown remained of vital importance to Chinese immigrants.

\section{CHINESE ORGANIZATIONS}

Family and kin played an important role in Chinese society, with mutual support and bonds between family members strengthening their power in negotiation with other groups and the larger society. Non-kin groups were formed to extend mutual support to those not in the same family or kin group. Mock kinship organizations also formed overseas. The earliest group of Chinese migrating into the U.S. were mostly males, and they were cut off from their accustomed ways of forming organizations along family and kinship lines. The value of kinship models as an organizational principle inspired them to form fictive kinship organizations to protect and support each other in the new environment. This practice enhanced trust and support among Chinese in a strange environment, enabling them to join more than one association inside Chinatown. 


\section{Clan associations}

The clan associations were formed by Chinese who had the same Chinese family name. They provided temporary accommodation for the newly arrived Chinese in the U.S. and helped them look for jobs, maintain contacts with their village people back in China and carry out ritual observances. In general, there were only a few strong clan associations in each Chinatown, and their influence over Chinatown matters was minimal.

\section{Tongs}

Tongs, also known as secret societies, were originally founded in Southern China to fight against the Ching Dynasty (Baker 1979). One of the major components of tongs is "blood brotherhood." Chinese individuals who joined tongs usually did not share any kin relationship, and in order for them to work with and devote themselves to each other, a swearing-in ceremony was prepared to initiate new members. Part of the ceremony included the drinking of wine which was mixed with blood taken from the fingers of the new recruits; thus, the new and old members became blood brothers. It was generally believed that Chinese secret societies in America stemmed from these associations in China. However, the aims of the tongs in America changed from overthrowing the Chinese government to providing protection and support for Chinese sojourners. Tongs were organized as refuges for individuals who were not from big surname groups, and thus 
could not seek help from their clans or family. Tongs defended their members against exploitation from the major clan or family associations, emphasizing fraternity and mutual assistance. The tongs dealt exclusively with the Chinese population without directly confronting non-Chinese. However, tongs also performed some negative functions. Tongs collected protection money from businesses inside Chinatown, and controlled the relationship between Chinese inside Chinatown and the larger society (Tsai 1986:52-54). Tongs were also well-known for inter-tong wars in which tongs fought each other in financial disputes or over other conflicting interests. They were also involved in smuggling, gambling and prostitution in the early days, eventually leaving a negative impression among both chinese and non-Chinese. Today, members of tongs emphasize the provision of places for members to socialize and gamble as their main roles.

\section{Huiguans and the CCBA}

The huiguans, also known as district associations, were organized by Chinese who came from the same districts in Guangdong Province. Huiguans provided accommodations and medical care for new Chinese immigrants, and they also settled disputes among individuals. Huiguan members mostly consisted of Chinese merchants or those who had families. In the 1860s, there were six big huiguans in san Francisco: the Hop Wo, Ning Yeung, Sam Yup, Yan Wo, Sze Yup, and Yeong 
Wo Huiguans. In order to settle constant conflicts and feuds in resource distributions among clan associations and the huiguans, these six huiguans sent representatives to form a board which had supreme jurisdiction within the community. Hence, Zhong Hua Huiguan, or the Chinese Consolidated Benevolent Association (CCBA) was formed.

After the establishment of the CCBA in San Francisco, other cities followed suit. Although the development process differed among Chinatowns, the CCBAs had the same goal: to serve the chinese community. For example, the objectives of the CCBA in Portland in the 1910 s were: 1) to fight illegal and unjust discrimination against chinese in business and as individuals; 2) to help chinese that experience unreasonable difficulties with U.S. immigration authorities; 3) to arbitrate disputes among chinese of different associations; 4) to run a Chinese language school and 5) to authorize or manage other activities for the common good of the Chinese community (Ho 1978:24). As the objectives reflected, the purposes of the CCBA largely reflected Chinese responses to immediate needs and the harsh treatment from the larger society.

The CCBA spoke for and represented all aspects of Chinese activities, hence, the CCBA became "an official government inside Chinatown and..... the most important voice of the Chinese immigrants speaking to the American officials" (Lyman 1974:33). Even after diplomats were sent 
from China to establish formal diplomatic relationships with the U.S., the CCBA continued to control the internal affairs of Chinatown. Although some have argued that CCBA control over the welfare, social, political, ritual and economic activities of the Chinese community further isolated Chinese immigrants from the larger society, it is important to remember that the formation of Chinatown was not the result of Chinese who intentionally isolated themselves from participation in white American society. Segregation and isolation had been forced upon them, and the controlling power of the CCBA inside Chinatown was reinforced by this situation.

The dominant power structure of the CCBA began to change in the 1940s after the Chinese Exclusion Acts were repealed. Chinese men were able to meet with their wives and children and formed families. Some of them moved out of Chinatown, and some devoted more time to family members, resulting in less involvement in activities organized by the CCBA, and thus, weakening the influence of the CCBA over those families. Also, second generation American Chinese who received higher education had more opportunities outside Chinatown and began to move away and live in suburban areas. Social service agencies were also established by new Chinese professionals, social workers and students aimed at helping Chinatown residents. Therefore, the once dominant CCBA leadership and its functions were challenged by these new 
forces in some big Chinatowns in the U.S. (Nee \& Nee 1972; Wong 1977; Kwong 1987).

\section{CHINESE IN OREGON}

Chinese began to move to Oregon in the 1860 s from California when gold mining opportunities were discovered in Eastern Oregon. During this time, most Chinese workers stayed in John Day and its adjacent towns. In the 1870s, the fish cannery business along the columbia river and in Astoria attracted more Chinese to move to Oregon, and they settled and worked in the Portland area after their seasonal jobs ended. According to Samuel's Portland Directory, in 1873 Chinese in Portland owned laundries, tailoring, clothing manufacturing and cigar businesses, while others worked as laborers, cooks, domestics and in mercantile employment. Portland's Chinatown spread from Southwest Front Avenue to Third Avenue, and from Southwest Ash street to salmon street, a total of fourteen blocks. In Sidney Warren's reminiscence, Portland's Chinatown in the 1880s was crowded with exotic shops and bazaars, laundries, fish markets, and restaurants over which wood awnings had been built as protection from the rain. The streets were constantly filled with loitering Chinese males, gossiping or shopping while the smoke from their tiny-bowled, enormously long-stemmed pipes hung overhead (Warren 1949:149).

Portland's Chinatown became a center providing support for seasonally contracted railroad workers, fish cannery 
workers and other local Chinese immigrants (Clark 1973). At the turn of the century, Portland had the second largest Chinese population in the U.S. with a total of 7,841 , and Portland's Chinatown had expanded to adjacent areas, although Southwest Alder and Second Avenue remained the center of Chinese activities. Both H.W. Scott and Percy Maddux provided detailed descriptions of the buildings and the activities inside Chinatown.

The buildings are intensely oriental in their general air, with piazzas of curved roofs, highly ornamented with yellow, white and vermillion paint, and paper globes and gewgaws.

Red paper inscribed with characters in black serve as signs, and are pasted numerously over doors and windows (Scott 1890:437).

...Hundreds of Chinese would transact their affairs in a single building, many of the buildings being rented from white people at enormous rates. Others conducted their business on the sidewalks, with their fruit stands, vegetable stalls, meat shops, chicken coops, and other paraphernalia (Maddux 1952:84).

The face of Portland's Chinatown continued to change after the 1920s. Chinese began moving out of Portland to other bigger cities for better job opportunities, leading to a drastic decline in the Portland Chinese population in the following decades. Chinese families also began to move out of Chinatown to Southeast Portland. In a study of Chinese population distribution in 1938 by Bessie Ying Lee, 40\% of the Portland Chinese population consisted of single men, and most of them lived in Chinatown. However, only $30 \%$ of the 176 Chinese families lived inside Chinatown, and 45\% lived 
on the east side of Willamette River (Lee 1938:24). This early movement of Chinese families outside Chinatown was unique among other Chinatowns in the U.S. This might be because Chinese faced less discrimination and hostility from white society in Portland, and in fact, Portland was one of the refuge cities for Chinese during the exclusion period. This was particularly because of the leadership of the Portland mayor and other citizens who organized and supported volunteers to enforce the law and keep order. Chinese in Portland were protected and escaped violence from anti-Chinese sentiment in Oregon. Chinese continued moving away from Portland's Chinatown into the 1960s, and Portland's Chinatown eventually became a non-residential center.

Chinese were allowed to attend public schools in Portland. Although they were not totally segregated from other children, the schools they attended were largely for Asians. In the 1940s, Chinatown began to decline along with the demolition of old tenements and shops. This resulted in more families moving out of Chinatown, and it no longer functioned to support Chinese with jobs and other opportunities. In the 1960s, the old site of Chinatown was taken over by city government for other development projects and Chinese activities were transferred and centered to the north of West Burnside street where the CCBA headquarters was located. 
Today, Portland's Chinatown is mainly a commercial center. Although there are a few single Chinese men in their sixties living inside Chinatown, all other Chinese have moved to other areas. A total of six Chinese restaurants, two grocery stores, one cafe, two gift shops, and a Chinese medical and herb store are found inside Chinatown. Thus, the major activity is concentrated in the restaurant business.

Since there are no residential activities in Chinatown and the Chinese population has dispersed throughout the Portland area, the influence of the CCBA on the Portland Chinese has diminished. This was reflected in their revised objectives written in the 1962 constitution which include only: a) to promote general welfare and good relations in the Chinese community, and b) to foster social, educational, and charitable endeavors in the community. Today, the Portland CCBA sponsors few events: an annual picnic for all Chinese, a banquet for Chinese high school graduates and administration of the Chinese Language School. Since the picnic and banquet are only organized once a year, the Language school has become the only regular activity.

Tongs began to move into Portland from San Francisco in the late 1880s, a time even earlier than the CCBA. In 1914, Hip Sing, Hop Sing, Suey Sing, and Bing Kung were the four tongs in Portland's Chinatown. The functions of the tongs were controversial. On one hand, they provided protection 
and legal aid to Chinese laborers, but, on the other, they controlled illegal gambling, prostitution and opium smuggling activities. Gambling was the major activity, and it became part of the lives of the Chinese inside Chinatown in the early 20th century. In the 1950s, the Portland police shut down all Chinese illegal gambling houses, which resulted in a large number of Chinese leaving Portland. Gambling eventually revitalized as a private club activity found mainly in the tongs, so that tongs today have become largely a place for old Chinese men to socialize and gamble on a small scale with each other.

The composition of tong members has also changed in the last two decades. Tongs usually recruited and were joined by single chinese males, but the new immigrants from China, Taiwan and Hong Kong have been mainly families, with no interest in joining tongs. Because it was hard for tongs to expand by focusing on new Chinese immigrants alone, they began recruiting among Vietnamese-Chinese youth. As a result, very few Hong Kong Chinese are involved in tong activities.

The Chinese Language School opened in 1918 in Portland, and offered both Cantonese and Mandarin classes to Chinese and non-Chinese. It was closed during WWII but has reopened and operated since then. Today, the school offers Cantonese and Mandarin conversation, reading and writing classes. Classes are open to all ages and divided into three levels: 
lower, intermediate, and advanced, and students are assigned to the appropriate level according to their language skill. Usually, they will move to a higher level after one school year, or remain on the same level. The school year begins in september and ends in June, and each student is charged $\$ 170$ for the whole school year. Classes run from $10 \mathrm{a} . \mathrm{m}$. to 1 p.m. every saturday. According to records from the language school, a total of 140 students attended during the 1992-93 school year. Most of the children's families were from China, Taiwan, Hong Kong, Cambodia and Vietnam. Among them, forty students' families were from Hong Kong. The library and office of the language school not only serve as a place for school business but also provide a place for parents and other Chinese to meet.

According to the 1990 U.S. Census of Population, there are a total of 13,746 Chinese in Oregon, with 9,011 living in Clakamas, Multnomah, and Washington counties. No exact figures of the number of Hong Kong Chinese residing in the Portland metropolitan area are available, but approximate numbers can be drawn from two sources: first, estimates made by prominent Chinese in Chinatown, and second, data drawn from the U.S. Department of Justice. Both sources suggest that about 1,200 to 1,500 Hong Kong Chinese immigrants now live in the Portland metropolitan area, and that they made up only a small percentage of the total Chinese immigrants in Oregon. (See Appendix C for further discussion). 
HONG KONG CHINESE IMPRESSIONS OF AND RELATIONSHIP WITH PORTLAND'S CHINATOWN

When asked about their impression of Portland's Chinatown, Hong Kong Chinese responded with particular interest in three aspects: the Chinagate, Chinese food and the atmosphere of Chinatown. "Backward" and "old-fashioned" were terms they commonly used to describe Chinatown.

\section{Chinagate}

Some informants pointed out that Chinatown is nothing but the Chinagate. Although they agreed that the Chinagate represented the existence of a Chinese community with a long history in Portland, they believed that its presence in Chinatown served more as a symbolic gesture than any practical use. Nevertheless, as revealed by some old-time prominent Chinese in Portland, the Chinagate conveys a message: more than merely welcoming everyone to Chinatown, it is also a physical hinderance preventing the city government from utilizing Chinatown for parking lots and other commercial purposes. Hence, it carries a strong political statement. This, however, is a hidden transcript not recognized by most more recent Hong Kong Chinese immigrants.

\section{Chinese food}

All of my informants mentioned that the greatest motivation for them to go to Chinatown is to eat, especially 
dim-sum. Lisa, who emigrated two years ago, responded that the first three months she was in Portland, she went to have dim-sum every day. Although dim-sum is a big attraction in Chinatown, most informants also revealed that they visited the place infrequently. In fact, most went to Chinatown only once or twice a month, ${ }^{1}$ both because the substandard quality of Chinese food inside Chinatown reduced their interests in returning, and, because Chinese groceries are available in other Asian grocery stores outside of Chinatown, so they do not see a necessity for going there.

\section{Atmosphere of Portland's Chinatown}

Hong Kong Chinese Americans commented on the lack of a prosperous atmosphere inside Portland's Chinatown. They pointed out that even during weekends, Portland's Chinatown is very quiet with very few Chinese visiting it. They also complained of a lack of other entertainment such as karaoke bars inside Chinatown. Its close proximity to drug activity areas also made them hesitate to go there. One informant, Leung, who has lived in Portland for 20 years, has urged the city government to join hands with organizations inside

$1 \quad$ Old and new Hong Kong Chinese practices differ slightly in this respect. Although they both visit Chinatown infrequently, the old Hong Kong Chinese Americans are very reluctant to have dim-sum in Chinatown. This might be because they are more thrifty and are able to make their own dim-sum. Therefore, they only go to have dim-sum on an important day like Mother's Day. 
Chinatown to bring a better and safer environment for the small Chinese community in Chinatown, symptomatic of a clear urge for change.

Hong Kong Chinese could not stop comparing what they had in Hong Kong and how they expected to find a place that resembled it, but this was not what they actually found. Clearly, Portland's Chinatown was a big disappointment to them. Joan, one informant, said that when she was in Vancouver's Chinatown in B.C., she had a feeling of returning back to the busy market in Hong Kong. However, she did not feel she belonged to Pórtland's Chinatown and complained that it had "nothing." Her frustration reflected why Hong Kong Chinese immigrants favored and praised Chinatowns in San Francisco or Vancouver, B.C. so much. When the issue of whether Chinatown deserved retention was raised among my informants, most of them agreed that they wanted to retain Portland's Chinatown. However, they recommended renovation to revitalize it. It is understandable that the group of Hong Kong Chinese Americans would like to have a taste of their old practices--the way to shop, to buy groceries, to entertain and to socialize with friends--in the U.S. Their negative impression of Portland's Chinatown could then be explained as a desire to change Chinatown to meet their specific "Hong Kong style" needs. 
However, Portland's Chinatown is unlikely to change in any way that measures up to their expectations. Portland will probably not attract large Hong Kong Chinese investments to its Chinatown in the near future, both because it lacks a large Hong Kong Chinese community to support such growth and change in Chinatown, and because the older Chinese immigrants from China would probably resist changes in their status quo and block any drastic changes. Therefore, the only chance for change would be if individual new Hong Kong Chinese immigrants found opportunities for investing inside Chinatown.

The relationship between Hong Kong Chinese immigrants and Portland's Chinatown is weak, and Hong Kong Chinese are seldom involved in Chinese community activities. ${ }^{2}$ Only three out of twenty-eight informants reported that they had joined in activities provided by the CCBA and clan associations. One informant attended a graduation banquet provided for Chinese high school graduates. Two had attended an annual picnic organized by the clan associations. The rest of my informants explained that they

2 Specifically Chinese community activities, i.e. activities organized by the CCBA, tongs, Chinese Social Service Center, clans, and family associations, but not activities organized by Chinese churches. Chinese church activities are regularly attended by church participants. However, most Hong Kong Chinese Americans do not attend any of these activities. Christian informants also did not mention their participation in any Chinese community activities other than the church activities. 
never heard any announcements about the activities or claimed that they were not interested in joining them. Such passive and uninterested responses are evidence of a lack of a sense of belonging and knowledge about Chinatown.

Hong Kong Chinese Americans also require minimal support from the CCBA or the Chinese Social Service Center. According to representatives of the Chinese Social Service Center, their clients mainly consist of Chinese from Mainland China and other ethnic Chinese from Cambodia, Vietnam and Laos. Very few clients come from Hong Kong. Social workers suggested that Hong Kong immigrants are financially able to support their families and are able to deal with the larger society independently. As a result, Chinatown and the Chinese Social Service Center are not places where Hong Kong Chinese find vital support.

So far, in Chapters three and four, we have discussed the changing faces of Portland's Chinatown in the last century, the differences between Hong Kong Chinese Americans and the older Chinese settlers, and Hong Kong Chinese Americans' relationship with Portland's Chinatown. Hong Kong Chinese's unique perception of and reaction to Portland's Chinatown illustrates their lack of a sense of commonality and a sense of belonging with Portland's Chinatown, and this could be explained by applying practice theory and the concept of habitus discussed in Chapter one. According to Bourdieu's practice theory and the concept 
of habitus, individuals' practices are shaped by their past experiences. For the group of Hong Kong Chinese immigrants, most of these past experiences occurred in Hong Kong. As discussed in Chapter three, Hong Kong Chinese Americans differ from Chinese immigrants from China in their command of English, urban city experiences and wealth ${ }^{3}$. Therefore, Hong Kong Chinese immigrants' hopes and eagerness for changes in Portland's Chinatown reflect the indelible experiences they had during their early lives in Hong Kong. Their lack of knowledge of overseas Chinese history, their stereotypic impressions of Chinatown and their lack of sentimental attachment to the place are due to a different set of life experiences which have shaped the way they view the world. It is not surprising that the older generation of Chinese immigrants continues to visit Chinatown more often than Hong Kong Chinese immigrants. Clearly, Hong Kong Chinese identity is not reflected in an attachment to Portland's Chinatown, but is rooted in a different set of past experiences.

3 Although this thesis will not investigate non-Hong Kong Chinese impressions of Chinatown, it is very likely that Hong Kong Chinese Americans have a closer relationship with long time Chinese settlers from the Mainland than they have with other non-Hong Kong Chinese Americans. This is because most early Chinese immigrants are of Toishan descent, and thus closely related to Hong Kong Chinese whose ancestors also come from Guangdong Province. But the Chinese from Taiwan have their ancestral homes in Fujian Province where language and customary practices differed considerably from those in Guangdong. 


\section{CHAPTER V}

\section{HONG KONG CHINESE ETHNIC IDENTITY CHANGES}

\section{THE STORY OF WONG}

Before turning to a discussion of the specific cultural traits which make up Hong Kong Chinese identity and the changes in practices related to them, this chapter will begin with the life story of one informant, a man I will call Wong. It is important to understand that wong is not stereotypic of Hong Kong Chinese Americans and cannot totally represent them. His experiences, however, do speak for some Hong Kong Chinese immigrants in many ways. Wong's life experiences, together with a discussion of cultural traits, will illustrate the value of practice theory and the concept of habitus in explaining the construction of ethnic identities.

Wong graduated from Baptist College in Hong Kong, and worked for the government before moving to the U.S. Like most Hong Kong Chinese, his close friends and acquaintances were Hong Kong Chinese. He lived an affluent and enjoyable life, spending his leisure time playing mahjong, gambling on horse races, eating dim-sum and taking overseas vacations. However, he was pessimistic about the political future of Hong Kong, and therefore, he decided to join his sister and 
mother in the U.S. Wong came to Portland, Oregon in 1980. Two years later, he married a young woman from Mainland China, and they had two daughters who were American-born. With the help of his relatives, Wong settled down in Portland quickly, and in a short period of time, he found a job working in the post office. Most of his colleagues are Americans, and he speaks only English at work. On weekends, he likes to go fishing, and, if his relatives are available, he might play mahjong with them. He spends his vacations visiting Hong Kong and Vancouver, B.C. where he claims the only "true" Chinese food is found.

Wong likes to speak Cantonese because he can express himself most clearly and freely in his native tongue. He hates to speak English with Chinese immigrants from Hong Kong, and claims that, since they come from the same place, they should talk in their own language. He has taken a strong stance on this issue and tries to speak only Cantonese at home. However, his children are more inclined to speak English since they began attending grade school. In order to push his children into learning Cantonese, he sends them to the Chinese Language School. Wong also has given Chinese names to his daughters and hopes they will think of themselves as Chinese and understand the meanings their names carry. He also hopes his childrens' spouses will be Chinese, although he acknowledges that this might be discrimination. 
Wong lives very close to his mother and sister, and they visit each other very often--especially on important days or festivals such as Mother's Day, Thanksgiving, Christmas and Chinese New Year. ${ }^{1}$ They usually gather at his mother's house to celebrate. Most of the food is prepared by his mother, and she usually reminds her children of the exact date of each traditional Chinese festival.

Wong was upset about losing all his best friends when he left Hong Kong, and he does not have any close relationships with American friends in the U.S. He claims that even though he is not very close to other Hong Kong Chinese in Portland, whenever he hears them speak Cantonese, he has a warm and affectionate feeling towards them. He knows that they share something in common.

In order to keep track of the development of Hong Kong, Wong subscribes to a Chinese newspaper directly from Hong Kong. Eventually, he has become the Hong Kong "information distribution center" among his Chinese friends. He also has paid frequent visits to Hong Kong (about two times in three years), and has been excited about the changes he has

1 Hong Kong Chinese Americans began celebrating Mother's Day and Christmas when they were in Hong Kong. Therefore, it is of no surprise that they continue celebrating these American holidays after migrating to the U.S. Because Thanksgiving is an important holiday in the U.S., Hong Kong Chinese Americans take this opportunity to see other family members, but the foods they prepare for this celebration are still Chinese. A further discussion of how they celebrate traditional Chinese festivals follows in the next section. 
observed in Hong Kong. When wong was in Hong Kong, his friends laughed at him because he had an accent when speaking Cantonese. From then on, he realized that some of his practices had changed.

Although wong has resided in the U.S. for many years, he has not developed a sense of belonging. He describes himself as a Hong Kong Chinese who lives in a place that does not "belong" to him. In reality, he knows he will stay in the U.S. and is prepared to learn more about the differences in American life. However, there are things and practices that make him feel alienated. Language and American social norms are two aspects that strike him most. He watched television to try to learn some aspects of American culture, but he soon found out that he could not share fun with his American friends, even in a joke.

Sometimes he did not know exactly know what Americans talked and laughed about or why.

Another issue that has puzzled wong is whether to become an American citizen. He struggled with this long before he was even able to apply for citizenship. He felt uneasy and a sense of betrayal of Hong Kong and China. Facing an American flag did not arouse positive sentiments towards the U.S. but only a stronger sense of alienation. Finally he settled on remaining a resident alien in the U.S. and is satisfied with his current situation. 
Wong's life experiences reflect some significant changes in the practices of Hong Kong Chinese Americans and the importance of Hong Kong Cantonese to them. The discussion in the next section--a look at Chinese cultural traits and the changes related to them--will help illustrate the usefulness of applying practice theory and the concept of habitus to an understanding of the identity of Hong Kong Chinese immigrants.

DISCUSSION OF HONG KONG CHINESE CULTURAL TRAITS

In order to examine the traits that constitute the cultural identity of Hong Kong Chinese Americans and to explore how these traits have changed, a set of ten cultural traits suggested by some Chinese was prepared in the questionnaire. Informants were asked to circle in the order of importance ( 1 being not important, and 5 being the most important) the ten traits and discuss their choices accordingly. The results are listed in Table 2.

Comparing the level of importance given by the informants to these traits with a discussion of their practices in the U.S., there appear to be noticeable changes among Hong Kong Chinese immigrants after they have resided in the U.S. Indeed, new practices are begun within the context of their habitus and regenerate according to their past experiences. The following discussion focuses on the ten cultural traits commented on by informants, in order of 
their relative importance as constituent elements of Hong Kong Chinese American identity.

\begin{tabular}{|c|c|c|c|c|c|}
\hline \multirow[t]{2}{*}{ Traits } & & \multicolumn{2}{|c|}{ Order of } & \multicolumn{2}{|c|}{ Importance } \\
\hline & 1 & $\underline{2}$ & $\underline{3}$ & $\underline{4}$ & $\underline{5}$ \\
\hline $\begin{array}{l}\text { a. speaking Cantonese } \\
\text { b. knowledge of Chinese }\end{array}$ & 0 & 1 & 3 & 4 & 20 \\
\hline history & 3 & 3 & 4 & 3 & 15 \\
\hline c. filial piety & 0 & 0 & 4 & 10 & 14 \\
\hline $\begin{array}{l}\text { d. ways of preparing } \\
\text { Chinese food } \\
\text { e. observing Chinese }\end{array}$ & 1 & 2 & 7 & 5 & 13 \\
\hline festivals & 7 & 2 & 6 & 3 & 10 \\
\hline f. place of birth & 4 & 6 & 6 & 4 & 8 \\
\hline $\begin{array}{l}\text { g. reading Chinese } \\
\text { books/magazines }\end{array}$ & 2 & 8 & 3 & 8 & 7 \\
\hline h. speaking Mandarin & 3 & 7 & 11 & 3 & 4 \\
\hline i. clothing & 8 & 9 & 8 & 2 & \\
\hline j. ancestor worship & 10 & 10 & 3 & 3 & 2 \\
\hline
\end{tabular}

Table 2: Hong Kong Chinese Americans' views of ten cultural traits $(\mathrm{N}=28)$

Speaking Cantonese

Cantonese is the major language spoken by Hong Kong Chinese and has been retained and used by them after moving to the United States. The percentage of Hong Kong Chinese Americans using Cantonese has remained very high (see Table 3). Although there is no significant correlation between the use of Cantonese and the sex or age of my informants. Table 3 shows that informants who use the most Cantonese in daily conversations tend to be those who have resided in the U.S. for the shortest period of time. Except for those who have married White Caucasian Americans or American-born 
Chinese, informants tend to speak mainly Cantonese at home and to speak English at work.

\begin{tabular}{|c|c|c|c|c|}
\hline \% of & number & sex & average & average length \\
\hline Cantonese & of & & age & of time \\
\hline use & informants & $\mathrm{M} / \mathrm{F}$ & & in U.S. \\
\hline 100 & 4 & $2 / 2$ & 39 & 5 \\
\hline $75-99$ & 9 & $4 / 5$ & 33 & 10 \\
\hline $50-74$ & 7 & $3 / 4$ & 38 & 15 \\
\hline $25-48$ & 2 & $1 / 1$ & 35 & 16 \\
\hline $1-24$ & 3 & $3 / 0$ & 30 & 16 \\
\hline 0 & 3 & $1 / 2$ & 42 & 17 \\
\hline
\end{tabular}

Table 3. Percentage of Cantonese spoken in every-day life $(\mathrm{N}=28)$

Also, there is a tendency for families with children born in the U.S. to use more English at home. ${ }^{2}$ Only four informants speak $100 \%$ Cantonese. One of them works in a Chinese church and has limited opportunities to use English. One works in a warehouse inside Chinatown where English is not needed. The other two informants have a very limited command of English and are reluctant to use English to communicate with other people. They are women who do not work outside of the house. When English is needed on occasions such as going to the bank, they will have their children speak for them. (See Appendix D for informants by informants' use of Cantonese).

2 Families whose parents have a poor command of English will use Cantonese to communicate with their children. However, children who are American-born Chinese will usually respond in English. 
Four informants speak only English. The main reason is that they all married Caucasian Americans and use only English at work. Although they will talk to their parents or relatives in Cantonese, this only happens once or twice a month. Therefore, they are unable to use Cantonese very often.

Most of my informants speak Cantonese at home, and they claim that their children are able to learn Cantonese from them. Therefore, they do not see sending their children to Chinese Language School as necessary. Only two out of fifteen informants do so. However, Wong realizes that his children will have fewer opportunities to practice Cantonese outside the family and wants them to have formal training in Chinese, so he sends his daughters to the Chinese Language School to learn Cantonese.

Although the advantage of being bilingual is one reason Wong gives for sending his children to learn Cantonese, he cannot disavow that he also clearly likes his children to speak his own language. Other informants explain that they have tried to inculcate their children with what they have learned and experienced. To some of them, the reasons for learning Cantonese are straightforward--Chinese should know Chinese, and it is shameful to not know any Chinese. They believe that knowing Cantonese is proof of their Hong Kong Chinese identity. Some realize that it is not practical for them to ask their children to learn how to write and read 
Chinese, but they are more than satisfied when their children speak their native language.

Thus, "Hong Kong Cantonese" ${ }^{3}$ is the one unique trait which most clearly constitutes a Hong Kong Chinese American identity. Hong Kong Cantonese carries identifiable features such as slang, colloquialisms and words easily distinguishable from other Cantonese spoken by non-Hong Kong Chinese. For example: "nei hœy na lœy 'wei' a?" (Where are you going for entertainment (to enjoy) tonight?) The word 'w $i$ ' is a slang term which means 'enjoy' and is commonly used among Hong Kong Chinese. The utilization of these identifiable features is uniquely associated with the daily lives of people in Hong Kong. In addition some informants pointed out that old Hong Kong Chinese Americans in Portland have an accent when they speak Cantonese and that they tend to speak more slowly than Chinese in Hong $\mathrm{Kong}^{4}$.

Another distinct characteristic of Hong Kong Cantonese is its mixing with English words. In the past ten years, it has become common practice for Hong Kong Chinese in Hong Kong to put English words into their Cantonese

3 Cantonese is widely spoken in the southern part of Mainland China, Hong Kong, Macau and among other ethnic Chinese in Southeast Asia. The term "Hong Kong Cantonese" is used to distinguish the Cantonese spoken by Hong Kong Chinese from other Cantonese speaking groups.

4 These two traits, in turn, could be used to distinguish Hong Kong Chinese Americans from Hong Kong Chinese. 
conversations. For example, "记 call ta answering machine, 92 Ilu bet dou message." (I called him and he didn't have an answering machine, so I couldn't leave a message.) In this example, the English words call, answering machine and message are used in the conversation. Hong Kong Chinese have brought this practice to the U.S. where more English words or even phrases are added to their Hong Kong Cantonese conversations. This is not found among old Hong Kong Chinese Americans because they had already left Hong Kong before this practice became common. They speak "pure" Cantonese as compared to the group of new Hong Kong Chinese immigrants who use a mixing of CantoneseEnglish language. Therefore, by focusing on English words found in Hong Kong Cantonese and on the different accents of Hong Kong Chinese Americans, it is possible to tell how long immigrants have been living in the U.S. and whether these people are having continued contact with Hong Kong. For general categorization purpose, it is plausible to say that 1) old Hong Kong Chinese Americans might have an accent in speaking Cantonese, but they include fewer English words or Cantonese slang in their Cantonese; 2) for the new Hong Kong Chinese Americans, more English words and Hong Kong slang are used in their Cantonese. The more slang or colloquialisms they know, the more likely their continued close connection with Hong Kong. Although the slang or words found in Hong Kong Cantonese could be learned by other 
non-Hong Kong Chinese by watching Hong Kong movies and videos produced in Hong Kong, the way they use the words and the accent they carry immediately signals their differences from Hong Kong Chinese Americans.

\section{Knowledge of Chinese history}

Most of my informants revealed that after they migrated to the U.S., knowledge of Chinese history suddenly became very important to them. Because of the changes in the cultural environment, they found themselves immersed in situations where they told other non-Chinese Americans about Chinese history and the history of Hong Kong. In particular, they were proud of describing the changes in Hong Kong, which showed how "smart" and "aggressive" Hong Kong Chinese are. Thus, they became more ethnically conscious. The interaction with other people aroused their sense of a Hong Kong Chinese identity. This further reinforced their urge to learn more about Chinese history and provided them with common grounds which drew them together in a foreign place.

\section{Filial Piety}

Filial piety is a major component of Confucianism safeguarded by Chinese for the last two thousand years, and a traditional belief deeply rooted in the Chinese mind. Filial piety is an important relationship between parents and children in the traditional Chinese family, where 
parents have strong parental authority and receive ultimate respect and obedience from their children. Hong Kong Chinese learned the importance of filial piety as they were raised, had it reinforced by school education, and found it emphasized in daily life practices. Even after moving to the United States, Chinese have strong feelings towards filial piety, and its expression has not seemed to fade away. They put filial piety into practice by taking care of parents. There are numerous examples in Portland of married Hong Kong Chinese Americans still living with their parents or the parents and their married children living close to each other so that the children can take care of them when necessary.

One informant, Victor, recalled that the date to open his restaurant was set by his father. Although his father did not have any ownership in the restaurant, the whole family obeyed him and followed his decision. Victor said that he wanted so much to pay respect to his father that he would not argue with him over the disadvantage of opening the restaurant on weekends. Thus, the way Hong Kong Chinese take care of their parents or pay respect to the elderly reflects practices clearly shaped by the beliefs in filial piety drawn from Confucian ideals.

The informants are well-aware of the importance of inculcating their children with this value. However, some are pessimistic about their children having a strong faith 
in this belief and, further, putting it into practice. For example, they do not expect that their children will necessarily take care of them in return. While keeping their hopes up, they are prepared to accept the changes. ${ }^{5}$

\section{Ways of preparing Chinese food}

The ways of preparing Chinese food varies among different regions in China: the north is different from the south, and Cantonese cuisine is different from other styles in the southern part of China. This difference is also a very special cultural trait that to some extent distinguishes Hong Kong Chinese from other non-Hong Kong Chinese. Hong Kong Chinese Americans shop mostly in major supermarkets like other Americans, but they also acquire items which supermarkets do not carry from Chinese grocery stores. According to my informants, their eating habits have been restricted by the lack of availability of Chinese food resources, such as Chinese herbs, and living seafood and farm produce such as fish, shrimp, chickens and geese.

5 Maybe the informants are overreacting to this situation. My observation among Hong Kong Chinese Americans shows very few examples of old parents having to Iive on their own without any support from their children. Of course, how the children behave when they grow up is always unpredictable. However, if the parents keep on passing the notion of filial piety to their children, the outcome might not be as pessimistic as they think. 
However, their ways of preparing Cantonese food have not changed much. ${ }^{6}$

Jimmy, the owner of a Chinese restaurant, values eating rice as very important. He claims that if he were to go without rice for three days, he would feel very weak and that Chinese have been addicted to rice for a long time. While this is a probable exaggeration, it was not unusual to find similar expressions among other informants. Rice draws its importance from its nature as a staple food which also fulfills psychological needs for Hong Kong Chinese Americans.

Food choices go hand in hand with ways of preparing Chinese food. Eating patterns are not easy to change after depending upon them for years; therefore, the limited supply of Chinese groceries in Portland has not necessarily restricted Chinese from practicing their old ways of preparing Cantonese style foods. Cantonese style cooking includes a lot of stir frying of food, thus, creating oily smoke. Even with a good ventilation system, it is not easy to deal with the smoke, and quite often the heavy smoke can trigger the smoke alarm and cause annoyance. Peter, one

6 Ways to prepare Cantonese food can also be found among the group of Chinese who came from Guangdong, China. Although some methods are uniquely found in Hong Kong, such as the way to prepare "Hong Kong style" red tea, in general, it is hard to distinguish the ways Hong Kong Chinese and Guangdong Chinese prepare their food. Thus, the trait is not regarded as a unique marker in identifying Hong Kong Chinese Americans. 
informant, demonstrated his family's unique way of blending Chinese cooking with an American house. His father turned a corner of his garage into a kitchen by setting up a work table and a stand to hold burner and wok, with a gas tank connected to the burner. Peter admitted that it looked funny when people walked by and found them cooking inside the garage, but they claimed that this is the best and only way to free the house from the permeating smoke that results from their way of cooking. This way of creating a "new" kitchen might be unusual among Chinese immigrants, yet, the phenomenon reflects deeply rooted practices not easily changed even when Hong Kong Chinese move to a new environment. For some old Hong Kong Chinese immigrants, food selections and practices will be affected by the preferences of their children. However, eating rice and Cantonese style cooking remain a common practice among most of the families. Therefore, while limitations on specific ingredients have forced some changes and adjustments in the food cooked, the core, as the example shows--the way to cook--has remained the same.

\section{Observing Chinese festivals}

Opinions split among my informants regarding the celebration of Chinese festivals. Some pointed out that observing Chinese festivals is no longer as important as it was in Hong Kong. Because there are no special activities organized by the government or other organizations as in 
Hong Kong, no celebratory atmosphere is created. Besides, they claimed that American holidays do not correspond with Chinese festivals, and they have to go to work on those days. This limits them from observing the festivals freely. Therefore, family members simply gather to have dinner for an important festival such as Chinese New Year rather than preparing elaborate celebrations. Since the festivals are recorded in the lunar calendar, they might be easily overlooked by the younger chinese generation, unless they are reminded by the elderly in the family who will also prepare ethnic foods to celebrate. Some informants claimed that even though they are unable to celebrate the festivals as they used to in Hong Kong, they will still remember the traditional Chinese festivals that accompanied them for years.

Government, mass media, and business promotion of Chinese festivals are missing in Portland, further reducing any enthusiasm for preparing a celebration. Yet, while there are Iimited celebrations of Chinese festivals in Portland, a couple of events have remained highly visible. The Chinese New Year Lion Dance and the Dragon Boat Festival draw wide publicity. However, these activities are not organized solely by the chinese community and actually attract very few Chinese. The dragon boat race is organized as an international competition, elevated from a local and traditional ceremony among Chinese to become an event 
involving local community participation and turned into a tradition of Portland. The lion dance in Chinatown attracts hundreds of people who come to enjoy it and watch on New Year's day. However, only a few Chinese attend, especially Hong Kong Chinese. Nevertheless, for those Chinese with a strong relationship with Portland's Chinatown, the event serves to convey a message to the general public of the existence of a Chinese community. The lion dance also goes beyond the exclusive performance for the Chinese community; the lion dance troup is often invited to perform for various celebrations and activities in the city that have no direct connection with or relationship to the Chinese.

Celebrations of Chinese festivals are usually accompanied by ethnic foods, such as rice cakes, rice dumplings, carrot cakes, moon cakes, etc. Since there is a lack of Chinese food items in Portland, old Hong Kong Chinese immigrants seem to have learned how to make the special foods necessary for celebrating these festivals. New Hong Kong Chinese immigrants, however, who were used to buying food directly from Hong Kong groceries, have found themselves with "nothing" to rely on. Thus, their eagerness to celebrate various festivals has been reduced.

\section{Place of birth}

It is a common practice for Chinese to ask where each others' place of birth is during conversations. Generation after generation, Chinese have remained interested in asking 
the same question, indicating a continuing identification with the place they have come from. Therefore, the same question was posed to my informants to understand how they would respond to it. My informants had diverse responses to this trait. Some informants claimed that the trait is not important because where they were raised is more important than where they were born. However, some informants pointed out that place of birth provided them with a Hong Kong Chinese identity, and thus, the trait is very important. Unfortunately, my informants could not think of anything to say about this trait which makes a clearer understanding of their choices impossible.

\section{Reading Chinese books and magazines}

Reading Chinese magazines and books are usual practices in Hong Kong which have become activities treasured by the Hong Kong Chinese immigrants. However, the opportunities for reading Chinese books and magazines are limited in Portland due to the very small supply of Chinese written materials. For some informants, this situation does not prevent them from looking for possible Chinese reading sources. Hong Kong Chinese immigrants will directly subscribe to Chinese materials from Hong Kong or San Francisco. For example, some of my informants subscribe to Sing Tao Daily from San Francisco. Reading Chinese newspapers and magazines helps them update the news from Hong Kong and assuages their nostalgia. It also serves 
those who do not have a good command of English but want to know what is going on around them. For some, reading Chinese materials proves to be more fun and easier than reading English. After all, Chinese is their first language. This practice not only continues their relationships with Hong Kong, but reinforces Hong Kong Chinese American identity. In respect to reading Chinese materials, there were no significant differences in practices observed between the old and new Hong Kong chinese immigrants.

\section{Speaking Mandarin}

Informants who think Mandarin is important base their belief on the premise that it is Guoyu (the language of the country) and Chinese should know this official language. Nevertheless, they also point out that they were raised in Hong Kong and did not have the opportunity to learn how to speak or use Mandarin, because only a few schools in Hong Kong offered Mandarin classes in their curriculum. Therefore, Mandarin has not been as useful to them, and not knowing Mandarin would not affect their Hong Kong Chinese identity. Speaking Hong Kong Cantonese is the more important factor in constituting their identity.

\section{Clothing}

As shown in Table 3 , there is a strong tendency for informants to regard clothing as an unimportant marker in 
claiming a Hong Kong Chinese American identity. Costume might be an important trait in identifying some ethnic groups or minorities in Taiwan, Mainland China, or in rural areas of Hong Kong, but it is less applicable to the majority of Hong Kong Chinese living in the urban areas. Traditional costumes (e.g., late Ching Dynasty and early Republican period) are not worn by Hong Kong Chinese today, and fashion in Hong Kong is much influenced by world trends, especially in Europe and Japan. However, several informants claimed that even without talking to Hong Kong Chinese Americans, they were able to tell where they came from only by observing how they dress. Some brands and logos not commonly found in Portland are worn by Hong Kong Chinese, such as Gordano (a Hong Kong base clothing manufacturer), and those who know fashion patterns in Hong Kong can easily identify them. New immigrants are still influenced by changes in fashion in Hong Kong because they pay attention to Hong Kong fashion trends and have made frequent visits back. Old Hong Kong immigrants have usually dropped such practices and are already immersed in local fashion trends. Thus, clothing may mark distinctions between more recent Hong Kong immigrants and those who have lived here longer, but it is not believed by most informants to be a very important component of Hong Kong Chinese identity. 


\section{Ancestor Worship}

Most of the informants responded that ancestor worship is no longer important to them and they have either dropped the practice or simplified the rituals. Five out of ten informants who regarded this trait as not important are Christians, and, therefore, it is not surprising to see them dropping the practices. Hong Kong Chinese in Hong Kong practice a simple daily ritual to worship their ancestors. Offerings include a cup of water, fruit and incense. On important days such as Chinese New Year, the offerings will include wine, food, and paper "spirit" money. But when Hong Kong Chinese move to the U.S., there are significant changes. Most informants claim that they will memorialize their ancestors in their heart but not necessarily perform any ritual practices. A few informants have retained the rituals by substituting incense with electric candles to avoid the danger of catching fire. Some young married informants point out that they had dropped these practices even when they were in Hong Kong and they would never think of revitalizing them in the U.S. Therefore, the practice of worshipping ancestors or providing offerings are not commonly found among either the old or new Hong Kong Chinese Americans.

Besides ancestor worship, other folk religious practices are also not found in many of the families. Although figurines such as Guan Yin or Guan Gong might still 
be found in some of the old Hong Kong Chinese American houses, they are no longer worshipped with offerings. Therefore, these figurines have become more of decorative items than objects for worship.

\section{CULTURE CHANGE AND PRACTICE THEORY}

Based on a different generative scheme of habitus (i.e. their early experiences in Hong Kong), Wong and other informants' practices and behaviors were shaped in a social context different from other non-Hong Kong Chinese, giving them feelings of shared similarities. Wong, for example, reported that he liked to hear people speaking Cantonese and was comfortable sharing his past and recent experiences in Hong Kong and the U.S. with other immigrants from Hong Kong. Experiences that wong had might also be found among other informants, and in fact, their discussion of the ten specific cultural traits illustrated similarities in their practices. The ten cultural traits help to reveal how some practices among my informants have been changed and some have remained. Hong Kong Cantonese remains the language in daily use for Hong Kong Chinese and the most important component of their Hong Kong Chinese identity. Speaking Mandarin is not important in Hong Kong and has remained unimportant after Hong Kong Chinese have moved to the U.S. Practices in preparing Chinese food and filial piety, although restricted by the changing environment, have also 
been retained. However, not all the traits have remained unchanged. Practices in ancestor worship and Hong Kong style clothing, are perceived as less important by my informants and practices associated with them have been reduced significantly. These traits are not regarded by them as important factors in their identity. Celebrating Chinese festival which was once regarded as important, is seen as less important by my informants. On the other hand, traits like reading Chinese newspapers and magazines, and knowledge of Chinese history which were of no special significance to my informants when they were in Hong Kong have become more important in constituting their Hong Kong Chinese identity. Hence, practice theory allows us to investigate the changes in practices among Hong Kong Chinese Americans in reference to historical context, and to the understanding of how my informants have come to recognize their identity. A new habitus is formed which is shaped by the shared experiences of Hong Kong Chinese immigrants in Portland. The most distinctive trait they carry is Hong Kong Cantonese, and other important traits include practicing filial piety, knowledge of Chinese history, and ways of preparing Chinese food.

My informants came from the same place with shared experiences. When in the U.S., they have faced and experienced similar changes. These past and current experiences have reinforced their cohesiveness. However, 
this sense of ethnic affinity was not one which was consciously developed. It was neither goal oriented, nor shaped in reference to particular rules, but arose from the commonality of experience and the habitus thus generated. These commonalities, which derived from the sharing of common practices at once unconscious and inculcated in the early experiences of life, have created ties to the past that are not easily broken.

Wong's experience furthers our understanding of how individual Hong Kong Chinese immigrants have reacted after immigration to the U.S. Although wong has tried hard to learn more American ways of behavior and the social skills needed to interact easily with Americans, his past experiences have made it difficult to do so. Being reared in Hong Kong, he was restricted by his past Chinese cultural environment from acting like an American today. He differs from his daughters who have received their education in the U.S. and have been exposed to American culture from early in life. Wong responds and acts unconsciously in his own Chinese ways which have already been ingrained in his mind for years, and it is not easy for him not to refer to his past experiences in the face of his new environment. As discussed in chapter one, early life experiences have a disproportional weight in shaping people's perceptions, interpretations and emotional reactions to daily life. By watching television or telling American jokes, Wong has 
tried to learn to think and to "act" like an American. On the other hand, Wong's frequent visits to Hong Kong suggest that, at the same time, his new experiences in Hong Kong have modified his practices in the U.S. Thus, practice theory and the concept of habitus help to explore the roots of where his likeness and commonalities coalesce with Hong Kong Chinese immigrants and how the sense of identity is rooted in their shared experiences.

Practice theory also helps us understand Wong's struggle with becoming an American citizen. He was educated in Hong Kong and was nurtured by traditional Chinese cultural values like filial piety. These values shaped his practices and his experiences but also became the objective base for his struggle. He lacked a fit in habitus between himself and those with whom he interacted in Hong Kong and America, but he found a sense of togetherness with the group of Hong Kong immigrants. His final decision not to apply for citizenship has allowed him to remain true to his own values with his strong ties to his Chinese tradition. He neither has sought to enhance his practical interests by becoming an American citizen, as instrumentalists would suggest; nor has he repaired to seek emotional support among his peers in Hong Kong, as might be suggested by the primordialist. Similar responses might be expected among the group of Hong Kong Chinese immigrants who shared similar experiences with Wong. After all, the formation of his 
identity as a Hong Kong Chinese American resulted from his shared experiences with other Hong Kong Chinese immigrants.

\section{SITUATIONAL CHANGES OF CULTURAL IDENTITY AMONG HONG KONG CHINESE AMERICANS}

Hong Kong Chinese in Hong Kong can identify themselves in a number of different ways under different situations. For example, in the village towns in Hong Kong where place of origin has carried great bearing in land ownership and the quest for local political and economic power (Blake, 1981), whether one is a Cantonese, Hakka or Hokkien Chinese often matters when interests and conflicts arise. However, when Hong Kong Chinese move to the U.S., identities such as Cantonese or Hakka, etc., do not seem to have the same significance, and new identity labels are used. ${ }^{7}$ In order to have a thorough and clear understanding of how Hong Kong Chinese might shift their identities and what kind of ethnic labels they associate with when different situations arise, the following section discusses situational identity variations among Hong Kong Chinese Americans.

The ethnic label Hong Kong Chinese usually identify with in the U.S. is "Hong Kong Chinese," an identity based on their adherence to traits previously discussed, such as

7 In informal interviews with Hong Kong Chinese immigrants, there was no suggestion that being a Cantonese, a Hokkien or a Hakka Chinese in Portland carried any special significance. 
speaking Hong Kong Cantonese, preparing Chinese foods in particular ways and practicing filial piety. Hong Kong Chinese are particularly aware of this identity when they are among Chinese from Mainland China or Taiwan. They believe that their Hong Kong Chinese identity implies both a different and a higher social status. Because of the economic success and the prominent financial status of Hong Kong in Asia, Hong Kong Chinese Americans are especially proud of being its citizens. However, while Chinese from the Mainland might attribute a higher status to their Hong Kong compatriots, Chinese from Taiwan do not necessarily agree with them. This may be because Taiwan has also enjoyed surging economic development.

Hong Kong Chinese are not limited to the label of "Hong Kong Chinese" but may identify with other labels as well. For example, they might, under different situations, shift their identity labels to "American," "Chinese," "Asian" or "Portlander." When, how, and why they do so can best be understood by returning to Nagata's ideas cited in chapter one which suggest that ethnic identity oscillation among individuals is affected by three factors: social solidarity and social distance; expediency; and social status and social mobility.

On some occasions, Hong Kong Chinese Americans will identify themselves simply as "Chinese, " particularly when interacting with other non-Chinese Americans where they wish 
to effectively distinguish themselves from other Asians, such as Japanese or Koreans. A shift of identity label to "Chinese" may also be compelling when international events, such as the Olympics, are played. This would be one of the few moments when Hong Kong Chinese feel proud of China's achievements and its competitiveness in some of the sports events with other nation-states. The 1992 Olympics provides a good example.

Hong Kong Chinese Americans were excited about the performance of Chinese athletes and their chances of winning different events. Moreover, they complained about how U.S. television networks broadcast events, focusing on American athletes even when a Chinese athlete won an event. They were also upset about not being able to see the prize giving ceremony which awarded a gold medal to the chinese athlete. Here their sense of social solidarity with other chinese clearly came to the fore.

One informant, simon, told of his feelings about being an American. Simon came to the U.S. seven years ago, yet said that when the national anthem was sung or when Americans celebrated their festivals, he had a strong feeling of not being an American but only an immigrant from Hong Kong. To him, these sensational moments could not arouse his emotions and cause him to switch his "Hong Kong Chinese" identity to that of "American." This might have been due to his relatively short stay in the U.S. Another 
informant who had been in the U.S. for fifteen years responded that he simply thought of himself as an American on those occasions. Again, this might have some bearing on the duration of a persons' stay in the U.S., how much the individuals interacted with a wider societal group, or how extensive their involvement in community activities were.

One occasion where Hong Kong Chinese readily claim an "American" identity without second thought is when they cross the U.S. border. At this moment, shifting to an "American" identity makes passing customs easier and reduces superfluous questioning by customs officers. This is particularly useful for those who only hold permanent residency in the U.S. Here expediency, as indicated by Nagata, allows Hong Kong Chinese to take advantage of oscillating their ethnic status successfully.

Hong Kong Chinese Americans seldom label themselves as "Portlanders." Again, it might be because they have not involved themselves in many community activities, allowing a sense of alienation to continue distancing them from the city. Clearly they see no advantage in accepting an immediate identification with a place which has inspired no special feeling.

Finally, Hong Kong Chinese also seldom label themselves as "Asians," unless conversations about the Asian world are involved, or there is a need to show a collective identity. On the contrary, "Asian" is used mostly by Americans, 
especially when they cannot identify specific Asian countries which "Asians" call home. George, another informant, commented that an "Asian" identity did not mean anything to him, except to suggest a geographic location from whence he came. Nevertheless, the term has been invoked by some Asians seeking better treatment from the larger society. For example, a panethnic campaign organized in California in 1978 called for Japanese, Chinese, and Koreans to form an alliance to request better treatment from the larger society. The alliance tried to take up issues of discrimination and mistreatment encountered by them since moving to the U.S. The major argument they made for such an alliance was that as Asians they received the same type of discrimination in the U.S.; therefore, they should unite to oppose such treatment.

However, the alliance never found unity or success. Two reasons explain its failure (Trottier 1981). On the one hand, Chinese who come to the U.S. have not had the same experiences as Japanese or Koreans, and thus, they have no foundation for their commonality. On the other hand, many Asians who come to the U.S. still have strong ties to their own countries. Countries in Asia are not homogenous, and each has its unique culture and history. The sentiment towards their native land and the relationship and conflicts that different Asian countries had in the past hundred years are still remembered by those in the U.S. Therefore, the 
bond for joining these people together based on their treatment in the U.S. is still far less strong than their bitter relationships historically.

The experience of overseas Asians or their families and their unforgettable histories make it hard for chinese to overcome such trauma and admit a panethnic identity in pursuit of economic and political interests, making fruitless any effort to encourage social solidarity among Asians and to use panethnic identity as an expedient way to gain advantages from the larger society. 


\section{CHAPTER VI}

\section{CONCIUUSION}

This thesis has attempted to examine and illustrate several issues raised in chapter one: 1) what different components constitute a Hong Kong Chinese American identity; 2) how have these components have changed; 3) how Hong Kong Chinese Americans shift their ethnic identities under different situations; and 4) how Hong Kong Chinese recognize commonalities among themselves as Hong Kong Chinese. According to the ethnographic data which I collected, among the ten cultural traits that were selected by some Chinese to exemplify their identities, Hong Kong Cantonese language is the one unique component which most clearly constitutes a Hong Kong Chinese identity. The features carried by this trait not only distinguish Hong Kong Chinese Americans from other non-Hong Kong Chinese, but the trait can also be used to identify different groups of Hong Kong Chinese who have resided in Portland for different periods of time.

Nine other cultural traits discussed resemble many of the practices Hong Kong Chinese Americans performed when they were in Hong Kong and also reveal significant changes since coming to the U.S. The filial piety trait remains a strong belief among Hong Kong Chinese. Hong Kong Chinese 
immigrants also have retained their usual ways of preparing Chinese food in the U.S., and see this as important to their Hong Kong Chinese identity. However, traits like ancestor worship, clothing, and Chinese festival celebrations have lost significance because of environmental restrictions and a lack of reinforcement by the chinese community. Speaking Mandarin is not an important factor constituting a Hong Kong Chinese identity, as reflected from my informants' lack of practice and emphasis on it. Reading Chinese newspapers and a knowledge of Chinese history have become more important since Hong Kong Chinese have resided to the U.S., even though practices associated with the traits are restricted by the availability of reading materials in Portland. The place of birth trait did not draw strong and clear opinions from my informants, and thus, did not seem to be very important in constituting a Hong Kong Chinese American identity.

The oscillation of identities among Hong Kong Chinese was also observed. They carry a Hong Kong Chinese identity when interacting with other non-Hong Kong Chinese and to distinguish their differences. Besides carrying a Hong Kong Chinese identity, they might also shift their identities to other categories when different situations arise. Therefore, categories such as "Chinese, "American," or "Asian" are also used by Hong Kong Chinese Americans on different occasions. 
The development of a Hong Kong Chinese identity is well understood by applying ideas raised by practice theory and the concept of habitus. Practice theory and the concept of habitus helps illustrate how the formation of a Hong Kong Chinese identity is developed through a sense of likeness and a feeling of commonality among the group of Hong Kong Chinese immigrants. This feeling of ethnic cohort among them is nurtured by their shared experiences which shaped their practices when they were in Hong Kong. After coming to the U.S., the altered practices of these Hong Kong Chinese Americans work to reshape their habitus, and thus, in return, reproduce new sets of practices. The characteristics of these new practices are produced within the context of Hong Kong Chinese immigrants' past experiences and their daily life in the U.S.

Hong Kong Chinese Americans have come to recognize their identities based on their objective shared experiences. This interpretation differs from explanations provided by the instrumentalist and the primordialist approaches which depict ethnic identities either in terms of political and economic interests or sentimental attachment to one's past. Practice theory and the concept of habitus provide a clearer understanding of the formation of Hong Kong Chinese identity, and I believe this approach could be usefully applied to the understanding of changes of ethnic 
identity among other non-Hong Kong Chinese immigrants in the U.S. as well. 
APPENDIX A

QUESTIONNAIRE 
APPENDIX A

QUESTIONNAIRE

I have prepared five sets of questions that I would like to ask you today. All information that you provide will be kept confidential and will only be used for my analysis. My research report will not identify anyone personally or in a manner in which others could recognize them. The first set of questions is about your personal background.

The sex of the informant is male/female

A. Personal Background

1. How old are you?

2. Where were you born?

3. What is your education level?

4. What languages do you speak?

5. Are you currently employed? Where? In what position?

6. What is your annual personal income? Please tell me the income range you are in: under $\$ 10,000$, $\$ 10,000-20,000, \$ 20,000-30,000, \$ 30,000-50,000$, over $\$ 50,000$

7. How long did you live in Hong Kong?

8. When did you come to the U.S.A.?

9. How long have you Iived in Portland?

10. In which part of Portland are you living now?

11. Have you lived in other places in the U.S.A. besides Portland? Where?

12. With whom did you come to the U.S.A.?

13. Do you have relatives in Portland? How often do you see them?

14. How would you describe your relationship with them? 
15. If you had some difficulty, would you call on them for assistance?

16. Why did you come to live in the U.S.A.?

17. What is your marital status?

18. Do you have any children? How old are they? where were they born? Have they married? Is their spouse Chinese? Are they living with you?

19. What percentage of your (i) close friends, and (ii) acquaintance are Chinese/non-Chinese?

How often do you meet them?

B. The next set of questions is about your opinions about Chinese identity. By identity, I mean that there are some traits that a group of people have chosen from their culture and exhibited so as to mark their similarities with and differences from other groups of people.

20. What components/traits do you think are important to exhibit your Chineseness (to show others that you are Chinese)?

21. Here is a chart of ten Chinese identity traits that were suggested by some Chinese. Please circle in the order of importance ( 1 being not important, and 5 being the most important) the ten items listed in the chart. We will discuss it after you are done.

\section{Items}

a. speaking Cantonese

b. speaking Mandarin

c. ways of preparing Cantonese food

d. clothing

e. ancestral worship

f. filial piety

g. place of birth

h. knowledge of Chinese history

i. observing Chinese festivals

j. reading Chinese books/newspaper

$\begin{array}{lllll}1 & 2 & 3 & 4 & 5 \\ 1 & 2 & 3 & 4 & 5 \\ 1 & 2 & 3 & 4 & 5 \\ 1 & 2 & 3 & 4 & 5 \\ 1 & 2 & 3 & 4 & 5 \\ 1 & 2 & 3 & 4 & 5 \\ 1 & 2 & 3 & 4 & 5 \\ 1 & 2 & 3 & 4 & 5 \\ 1 & 2 & 3 & 4 & 5 \\ 1 & 2 & 3 & 4 & 5\end{array}$

22. Can you explain the reasons why you chose such an order of importance for each of the items? 
23. How do you feel/respond when non-Asian Americans mistake you for a Japanese, Korean, or other SE Asian?

24. What do you believe are the major differences/similarities between Hong Kong Chinese and (i) Mainland Chinese; (ii) Taiwan Chinese; (iii) SE Asian Chinese; and (iv) American-born Chinese.

25. Can you identify someone who is from Hong Kong without knowing the person and talking to him/her? How can you tell they are from Hong Kong? What kind of traits do you look at in order to identify them?

C. This section is about your impressions of Chinatown.

26. How often do you go to Chinatown?

27. What attracts you to go to Chinatown?

28. Do you ever participate in any of the activities that are organized by the associations in Chinatown? Why or why not?

29. Do you think the preservation of Chinatown is important to you? Why?

D. The following section includes questions about your religious beliefs.

30. Do you ever worship your ancestors? When or where?

31. Have you ever worshipped the Buddhist, or Daioist Gods? Do you still practice it now? Where? Why or why not?

32. Do you attend a Christian church? Is it a Chinese Christian church?

33. Are there any particular reasons why you picked a particular church to join?

34. Have you been involved in any other types of religious activities? 
E. This section consists of questions that are related to your workplace, your home, and your activities.

35. During an average day/week, what percentage of your spoken language is Cantonese? What percentage is Mandarin and English?

36. What language do your children speak to you in?

37. Do your children have a Chinese/English name? Do you think it is important for them to have a Chinese name?

38. Would you mind if your child's spouse were not Chinese?

39. Do you read Chinese newspaper/books? How often? Why?

40. What are your favorite activities when you have leisure time?

41. Do you send your children to Chinese Language School? Why or why not?

42. Where do you like to shop?

43. What do you eat everyday? 


\section{APPENDIX B}

INFORMANTS' PERSONAL BACKGROUND 
APPENDIX B

INFORMANTS' PERSONAL BACKGROUND

\begin{tabular}{|c|c|c|c|c|c|c|c|c|}
\hline NNo. & Age & Sex & $\frac{\frac{\text { Years }}{\text { in }}}{\underline{\text { H.K. }}}$ & $\begin{array}{l}\frac{\text { Years }}{\text { in }} \\
\underline{\text { U.S. }}\end{array}$ & Education & $\begin{array}{l}\text { Lanquag } \\
\text { Spoken }\end{array}$ & & Occupation \\
\hline 1. & $50+$ & $\mathrm{F}$ & $50+$ & 2 & College & $C, \quad M$ & & Retired \\
\hline 2 . & 38 & $\mathrm{~F}$ & 36 & 2 & High Sch & C, M & & Res. owner \\
\hline 3. & 35 & M & 10 & 25 & Post-Grad & C, M, & $\mathrm{E}$ & Manager \\
\hline 4. & 43 & M & 25 & 18 & College & $C, E$ & & Manger \\
\hline 5 . & 39 & $\mathrm{~F}$ & 20 & 19 & College & $C, E$ & & Teacher \\
\hline 6 . & 21 & $\mathrm{M}$ & 19 & 2 & College & $C, E$ & & Student \\
\hline 7 . & 30 & M & 15 & 15 & College & $C, E$ & & $\begin{array}{l}\text { Church } \\
\text { Executive }\end{array}$ \\
\hline 8 . & 34 & $\mathrm{~F}$ & 19 & 15 & College & $C, E$ & & Engineer \\
\hline 9. & 35 & F & 28 & 7 & College & $C, E$, & $\mathrm{H}$ & Co. owner \\
\hline 10. & 21 & F & 17 & 4 & College & $C, M$, & $\mathrm{E}$ & student \\
\hline 11. & 21 & $M$ & 15 & 6 & College & $C, M$, & $\mathrm{E}$ & student \\
\hline 12. & 32 & M & 14 & 18 & College & $C, E$ & & Technician \\
\hline 13. & 32 & M & 26 & 6 & College & $C, M$, & $E$ & Clerk \\
\hline 14. & 34 & $F$ & 21 & 13 & College & $C, E$ & & Supervisor \\
\hline 15. & 36 & $\mathrm{~F}$ & 34 & 2 & College & $C, E$ & & Housewife \\
\hline 16. & 50 & F & 32 & 18 & High Sch & $C, E$, & $T$ & Cashier \\
\hline 17. & $4 I$ & M & 22 & 19 & High Sch & $C, E$, & $T$ & Postman \\
\hline 18. & 41 & M & 24 & 17 & High Sch & $C, E$, & $T$ & Res. owner \\
\hline 19. & 25 & $\mathrm{~F}$ & 13 & 6 & College & $C, \quad M$, & $\mathrm{E}$ & $\begin{array}{l}\text { Adm. } \\
\text { officer }\end{array}$ \\
\hline 20. & 42 & M & 40 & 2 & College & $C_{1}$ & & worker \\
\hline 21. & 39 & M & 18 & 18 & College & $C, M$, & $\mathrm{E}$ & Professor \\
\hline 22 . & 28 & F & 19 & 9 & College & $C, E$ & & Nurse \\
\hline 23. & 35 & M & 18 & 17 & College & $C, E$ & & Engineer \\
\hline 24 . & 48 & $\mathrm{~F}$ & 44 & 4 & High SCh & $C, E$ & & Res. owner \\
\hline 25 . & 36 & M & 22 & 14 & College & $C, E$ & & Manger \\
\hline 26 . & 33 & $\mathrm{~F}$ & 28 & 5 & College & $C, M$, & $\mathrm{E}$ & Secretary \\
\hline 27 . & 48 & M & 14 & 34 & High Sch & $C, E$ & & Res. Owner \\
\hline 28. & 42 & $\mathrm{~F}$ & 17 & 25 & High Sch & $C, E$ & & Clerk \\
\hline
\end{tabular}

Abbreviations: C=Cantonese, E=English, M=Mandarin, $\mathrm{T}=$ Toishan, H=Hakka, Res.=Restaurant 
APPENDIX C

ASSESSING THE NUMBER OF HONG KONG CHINESE IN PORTLAND 


\section{APPENDIX C}

ASSESSING THE NUMBER OF HONG KONG CHINESE IN PORTLAND

According to some prominent Chinese, the number of Hong Kong Chinese in Portland for the last 25 years has not exceeded 1,500. Their estimates come from their frequent interaction with and observation of the Chinese community. The number is close to the estimates deduced from data provided by the INS statistical yearbook.

Prior to 1952, the population census only recorded Chinese from Mainland China and Taiwan. Beginning in 1952, the total number of immigrants born in Hong Kong was recorded. In 1987, the record included a further breakdown of the specific state and metropolitan area where new immigrants intended to stay (see table below).

\begin{tabular}{|lccc|}
\hline & Arrival of Hong & Kong & Born Immigrants \\
\cline { 2 - 4 } Year & $\frac{\mathrm{U} . \mathrm{S}}{25,600}$ & $\frac{\underline{\text { Oregon }}}{\mathrm{N} / \mathrm{A}}$ & Portland* \\
$1961-70$ & 47,500 & $\mathrm{~N} / \mathrm{A}$ & $\mathrm{N} / \mathrm{A}$ \\
$1971-80$ & 25,700 & $\mathrm{~N} / \mathrm{A}$ & $\mathrm{N} / \mathrm{A}$ \\
$1981-85$ & 5,000 & $\mathrm{~N} / \mathrm{A}$ & $\mathrm{N} / \mathrm{A}$ \\
1986 & 47,000 & 23 & $\mathrm{~N} / \mathrm{A}$ \\
1987 & 85,000 & 66 & 58 \\
1988 & 97,000 & 76 & 59 \\
\hline
\end{tabular}

Number of Hong Kong Born Chinese Immigrants Arriving in Portland, Oregon and the U.S.: 1961-1989

* Figures for 1961-1986 not available.

Estimates then can be made from the data available. Hong Kong immigrants began to increase in 1984 was probably 
due to the joint-declaration of Chinese and British governments that Hong Kong will return to China in 1997. The increased number of immigrants from 1987 to 1988 was probably caused by the increased quota available for Hong Kong born Chinese in 1986. Since Oregon has not been one of the leading states in taking Hong Kong Chinese immigrants, the number of Hong Kong Chinese who migrated to Oregon prior to 1987 would not have been higher than 40 annually. This is based on the 1987 census that out of the 7,600 Hong Kong born Chinese who migrated into the U.S., 6,000 stayed in nine leading states, and only 1,600 chose the rest of the states, and, if the number is averaged by the number of remaining states, the average will be 40 . Using this figure to project the Hong Kong Chinese population in Oregon, from 1965 to 1976, the total number of Hong Kong born immigrants would not exceed one thousand. Given that the average number of immigrants in 1988 and 1989 was 70, and if this figure was used to project the numbers of Hong Kong Chinese immigrants coming to Oregon in the past five years, then, the number would be 350. If all of these premises hold, in the last 25 years, the total number of Hong Kong Chinese immigrants would be roughly 1,200, (this number does not include those who were not born in Hong Kong but were permanent residents), which in general agrees with the estimate made by prominent Portland Chinese. 
APPENDIX D

PERCENTAGE OF CANTONESE AND ENGLISH USE BY INFORMANTS 
APPENDIX D

PERCENTAGE OF CANTONESE AND ENGLISH USE BY INFORMANTS

\begin{tabular}{|lrrrrr|}
\hline Informant & Can $(\%)$ & Eng $(\%)$ & Informant & Can $(\%)$ & Eng $(\%)$ \\
\cline { 2 - 6 } 1. & 100 & 0 & 15. & 100 & 0 \\
2. & 95 & 5 & 16. & 0 & 100 \\
3. & 15 & 85 & 17. & 90 & 10 \\
$4 . *$ & 0 & 100 & 18. & 90 & 10 \\
5. & 50 & 50 & 19. & 80 & 20 \\
6. & 80 & 20 & 20. & 100 & 0 \\
7. & 100 & 0 & 21. & 30 & 70 \\
$8 . *$ & 0 & 100 & 22. & 50 & 50 \\
9. & 80 & 20 & 23. & 50 & 50 \\
10. & 90 & 10 & 24. & 70 & 30 \\
11. & 20 & 80 & 25. & 50 & 50 \\
12. & 20 & 80 & 26. & 70 & 30 \\
13. & 90 & 10 & 27. & 60 & 40 \\
14. & 40 & 60 & 28. & 80 & 20 \\
\hline
\end{tabular}

Abbreviations: Can--Cantonese, Eng--English, * Informant married to Caucasian American. 
REFERENCES

Baker, hugh D. R.

1979 Chinese Family and Kinship. New York: Columbia University Press.

Banton, Michael

1981 Direction, Reaction and speed of Ethnic Change. In Ethnic Change. Charles Keyes, ed. Seattle: University of Washington Press. pp.32-51.

Barth, Fredrik ed.

1969 Ethnic Groups and Boundaries: The Social. Organization of Culture Differences. Boston: Little, Brown.

Barth, Gunther

1964 Bitter strength: A History of the Chinese in the United States 1850-1870. Cambridge: Harvard University Press.

Bentley, Cater G.

1987 Ethnicity and Practice. Comparative studies in Society and History 29:24-55.

Blake C. Fred

1981 Ethnic Groups and Social Change in a Chinese Market Town. Honolulu: The University Press of Hawaii.

Bourdieu, Pierre

1977 Outline of a Theory of Practice. Translated by Richard Nice. Cambridge: Cambridge University Press.

Chen, Chia-lin

1972 A Gold Dream in the Blue Mountains: A study of the Chinese Immigrants in the John Day Area, Oregon, 1870-1910. Master Thesis in History. Portland state University.

Chen, Hsiang-Shui

1992 Chinatown No More: Taiwan Immigrants in Contemporary New York. New York: Cornell University Press.

Chen, Jack

1980 The Chinese of America. San Francisco: Harper \& Row. 
Clark, Hugh. R.

1973 Portland's China: The Foundation and Early History of a Community, 1850-1875. Unpublished Research Paper. Portland: Oregon Historical Society.

1975 Portland's Chinese: The Early Years. Portland: Center For Urban Education.

Department of Justice, U.S.

19881988 Statistical Yearbook of the Immigration and Naturalization Service.

19891989 Statistical Yearbook of the Immigration and Naturalization Service.

Epstein, A. L.

1978 Ethos and Identity: Three studies in Ethnicity. Chicago: Aldine.

Geertz, Clifford

1963 The integrative Revolution: Primordial Sentiments and Civil Politics in the New states. In OId Societies and New States, Clifford Geertz, ed. New York: Free Press. pp.105-57.

Ho, Nelson Chia-Chi

1978 Portland's Chinatown: The History of An Urban Ethnic District. Oregon: Bureau of Planning, City of Portland.

Keyes, Charles F.

1976 Towards a New Formulation of the Concept of Ethnic Group. Ethnicity 3:49-68.

Kung, $S$ W.

1973 Chinese in America Life. Some Aspects of Their History, Status, Problems and Contribution. Connecticut: Greenwood Press.

Kwong, Peter

1987 The New Chinatown. New York: Hill and Wang.

Lee, Bessie Ying

1938 Perceptuation of Primary Group Patterns Among the Chinese in Portland, Oregon. Master Thesis in Sociology. University of Oregon.

Lyman, Stanford $M$.

1974 Chinese Americans. New York: Random House. 
Ma, Qi

1989 The Representation of Ethnic Identity in the New Chinatown of Chicago. Unpublished paper. University of Chicago.

Maddux, Percy

1952 City on the Willamette: The story of Portland, Oregon. Portland: Binfords and Mort.

Manchester, Scott

1978 The History of Mutual Support Organizations Among the Chinese in Portland, Oregon. Master Thesis in Social work. Portland State University.

Nagata, Judith A.

1974 What is a Malay? Situational selection of Ethnic Identity in a Plural Society. American Ethnologist $1: 331-350$.

Nee, Victor G. and Brett De Bary Nee

1972 Long Time Californ: A Documentary Study of An American Chinatown. New York: Pantheon House.

Samuel's Portland Directory

1873 Portland: Geo, Himes, and Co.

Scott, Harvey $W$. ed.

1890 History of Portland. New York: D. Manson and Co.

Siegel, Martha $S$. and Laurence A. Canter

1991 U.S. Immigration Made Easy. Tucson: Sheridan Chandler Co.

Skeldon, Ronald

1990 Emigration and the Future of Hong Kong. Pacific Affairs $63(4): 500-523$.

Trottier, Richard $W$.

1981 Charters of Panethnic Identity: Indigenous American Indians and Immigrant Asian-Americans. In Ethnic Change. Charles Keyes. ed. Seattle: University of Washington Press. pp.272-305.

Tsai, Henry Shih-shan

1986 The Chinese Experience in America. Bloomington: Indiana University Press.

Warner, W. Lloyd and Srole Leo

1945 The Social Systems of American Ethnic Groups. New Haven: Yale University Press. 
Warren, Sidney

1949 Farthest Frontier: The Pacific Northwest. New York: Macmillan. 